\title{
Between Markets and Hierarchies: Law and the Constituting of Postcolonial Authority in the 'Imagined' American Republic, 1820-1850. From Discourse to Discipline
}

\author{
Mary Vogel ${ }^{*}$
}

In the aftermath of the American Revolution, leaders set about reconstituting political authority for a new world of self-rule. ${ }^{1}$ This paper explores the challenges they faced as they did so. This process of consolidating democratic transition in postcolonial America has recently assumed special relevance in light of the formative challenges faced by postcommunist societies, the European Union and post-conflict or divided societies experiencing unification and/or democratic transition today. ${ }^{2}$ This paper probes the practices and micro-processes through which authoritative postcolonial rule at the local level was established in America and set in motion. My claim is that ideas articulated in common law shaped the vision of postcolonial political authority that developed in late eighteenth and early nineteenth century America. In moving to create a justificatory vision of state action in the new republic, leaders drew on both the imagery of the rule of law and traditional arrangements of hierarchical household and community governance that had historically been elaborated in law. The courts, like political officials, had embraced social ordering as a prime concern.

These developments unfolded under the political stewardship of the American Whigs. Their control of elected office had waned due to extension of the franchise and the eclipse

* Professor and Chair in Criminal Law, School of Law, University of Manchester, UK; Associate Fellow, Rothermere American Institute, University of Oxford, UK; Associate Research Fellow, Institute of Advanced Legal Studies, School of Advanced Study, University of London, UK. References and bibliography begin on p 389.

1 The 'imagined republic' in the title refers to earlier work of the author's (Vogel 2007a and 2007b) which portrayed the new republic both as an 'imagined community' and as a 'social imaginary'. That work built on Anderson's (2006) depiction of nation states as 'imagined communities' and Taylor's (2004) and Stychin's (1995) works on communities of commitment as 'social imaginaries'. Recently, the author has also encountered Wilf's (2010) reference to an 'imagined republic' and that term is drawn on here.

2 Many look to the experience of the United States in the decades following the American Revolution as a potential model for how to unify and govern a diverse population democratically. 
of deference. Gradually, the project became one of 'hegemonic preservation'. ${ }^{3}$ Elite members of that party struggled to reconsolidate their beleaguered political power. ${ }^{4}$ To do so, they turned to the courts. Our findings suggest that law, which had during the late eighteenth century played a subversive and mobilising role in the American Revolution, now, paradoxically, took on a counter-transformative, and thus somewhat counterrevolutionary, tone. Despite much rhetoric of 'freedom' and 'market revolution', ideas of hierarchy played a key role in shaping thinking about authority during these years. In this process, the discourse of the rule of law became the basis for a disciplinary regime focused on social ordering. This paper suggests that, even as law contributed to the making of postcolonial authority, the American experience was far more complex and fraught with both subversive and counter-revolutionary dynamics than many have thought.

Creating political authority is crucial to democratic transition because any need to use force to uphold order undercuts a polity's claim to reflect the will of the people. ${ }^{5}$ In an earlier article, 'Embedded Liberty', I examined the development of a concept of citizenship in postcolonial America as a shared performative commitment to liberty that established membership in the new republic as an imagined community. ${ }^{6}$ The liberty embraced was, I argued, of a particular 'embedded' sort. In 'Embedded Liberty', my work contributed to debates about prevailing conceptions of freedom and the emergence of republican citizenship. It argues that the dualistic vision of 'embedded', or structurally constrained, liberty, elaborated by the courts, shaped that project. ${ }^{7}$ This current paper builds on and moves beyond that earlier work.

In this current article, I focus on efforts in postcolonial America to sustain social order through compliance and without resort to force by articulating a new vision of political authority. Though we now tend to associate the 'rule of law' with democratic state building, our knowledge about the precise nature of law's role in that process is still quite spare. ${ }^{8}$ Here I contribute to current debates about the role of the common law in the process of state formation in early nineteenth century America. ${ }^{9}$ I suggest that law, and the common law in particular, played a greater role than many have previously believed. In this paper, I ask what, specifically, was the role of law in the process of articulating a vision of political authority. As a corollary, I query what part it played in shaping the nascent American state. I start from a presumption of social transformation as an ongoing

4 There being no Tory Party equivalent in the United States, the American Whigs emerged as the party of both old and new money.

5 Vogel 2008.

6 Vogel 2007b.

7 Sources of primary data for this paper are drawn from a database constructed by me for a study of the origins of plea negotiation in criminal cases, or plea bargaining, in the courts of 19th century Boston (Vogel 2007a).

8 See particularly Skowronek 1982; Novak 1996; Orren 1991.

9 Novak 1996. 
historical phenomenon in which law and legal processes play a constitutive part. Mechanisms, events and choices through which such metamorphosis occurs are explored. ${ }^{10}$ Implications of language and contestation in shaping consciousness, human development and action are highlighted. ${ }^{11}$

\section{COMPETING INTERPRETATIONS OF THE ROLE OF LAW IN AMERICA'S 'FORMATIVE ERA'}

Prior to the American Revolution, Reid and Shalhope have suggested that familiarity with the rule of law and the British constitutional tradition of collective and individual rights fanned mobilisation in response to perceived excesses by the colonial governors in taxation practices, the quartering of troops and other matters. ${ }^{12}$ I argue that the common law continued afterwards to shape thought about postcolonial governance, authority and, especially, legitimacy. By the 1830s, however, struggle had arisen in America over the imagery of the rule of law. Both ruling Whigs and insurgent Democrats sought to appropriate the discourse of the 'rule of law' to their own partisan purposes. At this point, I suggest, the discourse of a 'rule of law' was used by the American Whigs in their effort to reconsolidate and reproduce elite power against the stirrings of popular politics. Thus, the discourse in their hands assumed, from a Democratic viewpoint, a counter-transformative tone. In this context, I argue that not just enacted statutes and judicial decisions but also the institutional practices of the courts must be studied to understand law's workings during this crucial period. How, I ask, could law, which had been a subversive force, so quickly take on counter-revolutionary meanings? ${ }^{13}$

My work builds on William Novak's book The People's Welfare, which, among others, has challenged much prevailing wisdom about the influence of American law in the nation's 'formative era'. ${ }^{14}$ Novak contests what he terms a 'liberal mythology' of law's role, focused on the constitution, rights and laissez-faire market activity in early to mid-

10 Thompson 1963; Katznelson and Zolberg 1988; Giddens 1987.

11 Sewell 1980.

12 Reid 1978; Shalhope 2000.

13 As JR Pole (2000) notes, the Continental Congress adopted the statement 'all men are created equal' as the 'fundamental moral precept' of the Declaration of Independence. Indeed, the American Declaration makes this statement explicitly in its opening lines. Pole reminds us of the priority accorded to equality in the Revolutionary movement when he says: 'But equality is prior to and more fundamental than [even] liberty in the canon of American principles: for if all men, or all persons, are equal in rights, then all must be equal in their right to liberty; no single American can have a greater right, or a right to more liberty, than any other. Thus, the Whig project that attempted to stabilise an increasingly unequal social order ran counter to the egalitarianism as a legacy of the American Revolution that Jacksonian Democrats sought to foster.'

14 In forthcoming work, I show that the legal sensibility of this society may be less fully monolithic than even these recent critics have supposed (Vogel forthcoming). My next work demonstrates how competing social groups appear to have struggled to appropriate and adapt to their own political visions the symbolic power of the language and imagery of the prevailing discourse of the 'rule of law'. 
nineteenth century America. Instead he proposes a vision of a 'well-regulated society' rooted in common law and committed to the 'people's welfare'. ${ }^{15}$ In this paper, I probe the precise role that the common law played in articulating a new vision of post-Revolutionary political authority suited to a world of, first, republican and, then, democratic, self-rule. Our approach to the common law is broadened to consider law as part of a regulatory project that includes legal institutions, especially the courts, and their practices. I highlight contestation over the content and operation of law. My focus here is on the legal culture of Massachusetts, which was a hub of legal innovation that spread by diffusion elsewhere.

Many scholars have interpreted nineteenth century American political and legal history as a period of the rise of market society and of liberalism. ${ }^{16}$ Recently these ideas have been challenged. In addition to Novak, scholars such as Stephen Skowronek, ${ }^{17}$ Lawrence Friedman and Harry Scheiber ${ }^{18}$ and Karen Orren ${ }^{19}$ argue variously that the liberal administrative state and/or laissez-faire markets arose in the United States only after mid-century. Others point to extensive regulation of markets and everyday life in early nineteenth century America to further counter ideas about free markets during that period. ${ }^{20}$ Together these arguments paint a picture of life that was extensively regulated until the Civil War despite only a limited state presence locally. ${ }^{21}$ How then could regulation be implemented without more significant local institutions of governance? To respond to this seeming anomaly, my work, following Skowronek, shows that the courts stepped forward as agents of the state, working to interpret and apply statutes and ordinances - regulatory and otherwise-within the framework of the common law. Much like the Quarter Sessions in England during the 1830s, they simply assumed for themselves an expanding range of local tasks and operations. ${ }^{22}$ In the fabric of their decisions and practices, judges articulated, I suggest, a policy sensibility that became the basis of a new symbolic code of local governance. A 'postcolonial' American approach to political authority took shape in this context.

My work shows that the conception of political authority that emerged was intertwined with and profoundly influenced by the vision of 'embedded liberty' that was elaborated by the courts. ${ }^{23}$ It was an understanding of freedom that was, paradoxically,

15 Novak 1996.

16 Sellers 1991.

17 Skowronek 1982.

18 Friedman and Scheiber 1988.

19 Orren 1991.

20 Novak 1996; Ferdinand 1992.

21 Apart from elected officials, a few constables and a much-criticised volunteer night watch, the primary agents of the state active locally were the tax collectors and the courts.

22 Nicola Lacey (2001a, 2001b, 2008 and 2010) has commented on the development of both punitive retributive and utilitarian regulatory strands of law during the 19th century in England.

23 Vogel 2007b. 
consistent with hierarchy. This vision, along with the decisions and practices it engendered, proved crucial to the project of imagining and setting in place authoritative justifications for state action to both sustain social order and reconsolidate Whig power. While the rhetoric of that day touted liberty in terms drawn from Locke, Kant, Paine, Montesquieu, Burke, the Scottish moralists such as Adam Smith, Rousseau and Bentham, ${ }^{24}$ among others, the courts moved openly toward a different interpretation of freedom. It was one that highlighted formally free choice, or autonomy, in a procedural sense while, at the same time, acknowledging the existence and legitimacy of powerful forms of constraint by the social and economic forces amidst which choices were made. This was an understanding of freedom that came to be articulated under Whig political dominance and, as it reinforced the existing social order, it consolidated the inequalities embodied in it. ${ }^{25}$ What this Whig vision of 'embedded' liberty does, however, is to direct our attention to the courts and the common law as a crucial arena in the constitutive process of democratic state formation and, for our purposes here, in the making of postcolonial political authority in America.

In thinking about law from its regulatory aspect, Michel Foucault reminds us that modernity has long seen the rise in the shadow of the state of disciplinary regimes, which, along with the formal juridico-political power of the state, are part of the broad project of society's social control. He argues that disciplinary power takes the form of surveillance, classifying and social sorting. While there is much debate about the relation of disciplinary power to the state, it has been argued with increasing frequency that the state, at a minimum, borrows the tactics of the disciplines. ${ }^{26}$ It is precisely such an interplay of legality and disciplinary power that, as we shall see, unfolds here.

In what follows, a first section suggests a theoretical perspective from which we can analyse this problem. A second explores the place of 'rule of law' discourse in providing the foundational imagery for a new conception of authority. A third section considers the contours of and forces at work in shaping the social order in which that vision of authority would have to function. Fourth, I examine the conception of authority that took shape in this context, showing how it drew on the imagery of a 'rule of law' for legitimation and on the common law and customary notions of governance for much of its practical effect. Fifth, I reflect on how this conception of authority, as a consequence of how it was framed, strengthened both the existing social order and, as a consequence,

24 Locke 1690 and 1773; Kant 1784; Paine 1776; Montesquieu 1750; Burke 1790; Adam Smith 1776; Rousseau 1762; Bentham 1789.

25 Vogel 2007a and 2007b; Pole 1978. As a consequence, I show elsewhere that the story of liberalism in America between 1830 and 1850, when the Whig party collapsed, is in large part one of its rise not as a theoretical project but as an oppositional discourse among Democrats (Vogel 2007a and forthcoming). It reflected Democrats' efforts to reclaim concepts of liberty and citizenship away from the Whig vision of 'embedded liberty' and toward one rooted in autonomy and rights that was more consonant with their own lived experiences and interests.

26 Barron 2002; Tadros 1998. 
the hierarchical inequalities within it. Sixth, I demonstrate briefly how this approach to political authority transformed the discourse of a 'rule of law' into a disciplinary regime of governance. ${ }^{27}$ Seventh, I suggest that the way discursive imagery and disciplinary tactics are combined in constituting a justificatory framework of political authority point to a path for conceptualising analysis of the common law as a system of social control anchored in the many practices of discretionary informality and leniency it embodies. Finally, I conclude by considering the capacities and limitations of liberal constitutionalist, instrumentalist and regulatory approaches to law to explain the dynamics operating to produce this blended form of authority.

This study is essentially a comparative one in design. The paper starts from a classical model of rational-legal authority proposed by Max Weber. ${ }^{28}$ I then examine the context in which the project of social ordering was tackled. From there I go on to explore whether developments in social ordering in postcolonial Massachusetts converged with or diverged from that classical model. To the extent that divergence is evident, and we will see that it is, we then ask if that departure, or distortion, from a purely law-based justificatory scheme for state action can be characterised in terms of the co-appearance of disciplinary power on the Foucauldian model as a transformative reinforcement for the discourse of a 'rule of law'.

\section{FOUCAULT, GOVERNMENTALITY AND LAW 29}

Much has been made of the fact that Foucault tends to depict the state as 'juridical and negative'. ${ }^{30}$ Yet, in his emphasis on society's middle-level institutions, discourses and processes of classification and social sorting as sources of power, Foucault has much of use to say about ways of seeing law, in general, and the common law, in particular. In his work, Michel Foucault turns our attention to the decentralisation, pervasiveness and multiplicity of forms of power as well as how power is acquired, exercised and reproduced. He probes the ways power and domination operate and shape modes of social classification and patterns of mobility. Foucault also highlights a shift in the manifestation of coercion from physical brutality to 'gentle' or symbolic violence. ${ }^{31}$ Best known for imagining power from a biopolitical perspective that limits the pivotal role of the state, Foucault emphasises its basis in the body as well as its many forms and locales. He critiques Marx for viewing power too economistically and in a way too concentrated in

\footnotetext{
27 Vogel 2007b.

28 Weber 1978.

29 I acknowledge in this section the broad interpretive influences of Ann Barron, Jonathan Simon, George Steinmetz, Colin Gordon and Patrick Hanafin beyond the specific attributions noted in the footnotes.

30 Foucault 1980, p 121; Steinmetz 1993, p 37.

31 Foucault 1984, p 254; Steinmetz 1993, p 35.
} 
the formal mechanisms of the juridico-political power of the state. As part of that critique, Foucault explores the diversity of modes of power and seeks to show its many decentralised institutional and cultural manifestations. Though critical of the project of law during the early years of his career as a form of power that is inherently restrictive, Foucault moved later to an intense interest in law, governing and social regulation. That theorising blossomed in his work on governmentality. Foucault sees law as one particular form of power, specifically state coercion, and locates it as part of society's broader regulatory venture of social control. ${ }^{32}$ As modernity has brought heightened attention to governance, law's importance has grown and it has become, according to Foucault, a key instrument in the state's repertoire of power even as legality has interpenetrated other, largely private, regimes as well.

In his analysis of social control, Foucault emphasises knowledge, discourse and the middle-level socialising institutions of society as vehicles for the exercise of power. ${ }^{33}$ Though sometimes alleged to have rejected any role for the state due to his contention that 'power isn't localised in the state apparatus', Foucault explicitly counters such a view, saying that 'relations of power... [simply] extend beyond the limitations of the state'. ${ }^{34}$ Overemphasis on the state as the locus of power tends, Foucault argues, to lead to a view of power as generally 'negative'. ${ }^{35}$ Foucault acknowledges that the phenomenon of 'governmentality', whereby a state characterises social problems and, thus, designates a target population for action and a range of possible solutions, can play a highly influential, and even creative, formative social role. Typically, such a diagnosis produces a discursive shift that reflects this new understanding. In his analysis, Foucault actually replaces sovereignty of the state with the more fluid image of a mobile field of force relations. ${ }^{36} \mathrm{He}$ also rejects the state-civil society dichotomy as tending to over-idealise society as a 'good, lively and warm ensemble'. ${ }^{37}$ For Foucault, society exercises perhaps its most extensive power through its role in the project of social classification and, through it, control. Here his primary focus is on disciplines, practices and institutions of control that operate outside or parallel to the formal framework of law. Foucault sees the disciplines as intertwined, but also in tension with law. ${ }^{38}$ These disciplinary mechanisms, which operate in the shadow of the state, exert their power by classifying, sorting and socialising. Institutions of carceral control such as asylums, hospitals and prisons are classic examples. Relying on techniques of surveillance and information gathering, these institutions and their practices 'naturalise' the process of control. As the disciplinary apparatuses have grown in power, one sees, according to Foucault, the appearance of processes of normalisation,

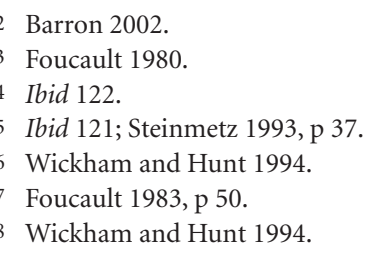


or socialisation based on self-regulation to norms, complementing and, sometimes, somewhat interpenetrating or displacing the role of law. For the subject of the disciplines, it is not enough to simply avoid breaking rules. Instead one must embrace prescribed standards which are internalised and used as a guide for self-regulating one's behaviour to it.

One of Foucault's most interesting lines of argument is his proposal that state action, as a specific form of power, can be analysed in terms of its deployment of positive techniques and strategies of power, which he refers to as 'governmentality'. By governmentality, he means the constituting of problems as targets for specific types of government action. ${ }^{39}$ One intriguing facet of Foucault's portrait of the state is his vision of historical transitions in approaches to 'governmentality'. Sketching four phases, Foucault points to: pastoralism; the early monarchic state; the 'police' state; and the modern legal welfare state. ${ }^{40}$ Individualising in its focus, pastorship was based on a 'shepherd's particular knowledge of each of his 'sheep' and stood in contrast to the subsequent 'centralised and centralising' power of the modern state from the Renaissance onward over a people. ${ }^{41}$ During the second phase, that of the monarchic state, power was both 'individualising and totalising' ${ }^{42}$

By the mid-seventeenth century, as monarchial absolutism drew to a close, Foucault observes a shift in concern on the part of the early modern state away from the 'divinity' of the prince and the cultivation of princely power to a focus on how to introduce 'economy' and prosperity through processes of social 'ordering' to everyday life. ${ }^{43}$ Foucault is focusing historically here on the years from the emergence of cameralist use of social regulation to promote state social policy goals of prosperity to the rise of the professional expert in a context of large scale institutions and the social welfare stateapproximately the mid-seventeenth to the late nineteenth centuries. In contrast with the pastor, who fostered the lives of individual subjects, and the early state that was focused on princely power, the modern state, according to Foucault, emphasised ordering through social regulation. It relied increasingly on processes of 'normalisation', which impinged on the body and worked largely through schemes of classification that, particularly later, included those of law. ${ }^{44}$ With the rise of the welfare state, Steinmetz has noted, we see a return to some of the state's earliest characteristics for it is both a 'universalizing legaljuridical form of sovereignty ... as well as "pastoral power wielded over ... individuals". ${ }^{45}$ Thus, the state today for Foucault provides a combination of 'security' and 'discipline'. ${ }^{46}$

39 'Cameralism and Police Science' in Rabinow 1984.

40 Foucault 1984, p 227.

41 Ibid 227; Steinmetz 1993.

42 Foucault 1982a, p 208; Steinmetz 1993, p 38.

43 'Cameralism and Police Science' in Rabinow 1984; Steinmetz 1993, p 38.

44 Steinmetz 1993, p 38.

45 Foucault 1984, pp 235, 237, 254; Foucault 1988a, 1988b and 1980; Steinmetz 1993, p 38.

46 Steinmetz 1993, p 38. 
Despite Foucault's many criticisms of Marx, his view of discipline as a strategic state approach to work, economy and welfare represents a link with Marxian analysis, though Foucault leaves ambiguous his sense of the precise nature of the relation of state activity to capitalism, markets and other arenas of power. Transition from one phase of governmentality to the next also remains an open question, with Foucauldian genealogy tending to rely on his vision of ruptures and social discontinuities punctuating historical change. In part, this ambiguity may stem from Foucault's vagueness as regards the nature and extent of human agency. Though he alludes to human resistance in the face of power, Foucault does little to articulate a social psychology of the human subject or to elaborate positive agentic strategies or lines of action. His most extensive treatment is probably his reflection on the constituting of the person in 'The Subject of Power' ${ }^{47}$ Perhaps most intriguing of all from the standpoint of this paper, Foucault almost completely sidesteps the rise to pre-eminence of democracy as a form of governance.

Among those who work in the Foucauldian tradition, Jacques Donzelot and Francois Ewald continue to focus on the socialising influences of middle-level institutions. In particular, they contend that, where social policy emerges as a state concern, a new sphere of life, which they refer to as the 'social', is constructed that is characterised by 'solidarity', bonds of social reciprocity between social classes', and the 'socialization ... of risk ... [through] social insurance'. ${ }^{48}$ Focused primarily on legal text rather than juridical practice, their vision of 'la société assurantielle' downplays rights in favour of duties or responsibilities and largely bypasses matters of conflict. Instead they showcase a focus on the mutuality to which these developments give rise. For this study, Foucault leads us to ask what role state 'governmentality', discursive power and society's mid-level institutions might have played in the process of reconstituting political authority in postcolonial America.

\section{THE LIBERAL INDIVIDUALIST INTERPRETATION AND ITS CRITICS ${ }^{49}$}

New scholarship proposes a picture of a 'well-regulated society' committed to the 'people's welfare'. In doing so, it challenges a much older and enduring tradition of interpreting nineteenth century American history from the standpoint of 'liberal individualism'. ${ }^{50}$ Novak's is the latest in a series of important critiques, including a prior instrumentalist one, of so-called 'liberal mythology'. In its early and perhaps best-known form, the 'liberal' interpretation focused on 'American constitutionalism' which high-

47 Foucault 1982b.

48 Donzelot 1984, pp 108-10, 175; Ewald 1987, pp 10, 327; Steinmetz 1993, p 39.

49 In sketching the contours of successive generations of legal thinking here, I am indebted particularly to William Novak's superb treatment in The People's Welfare (1996).

50 Novak 1996; Friedman and Scheiber 1988. 
lighted an independent judiciary that protected private property, personal liberty and a national framework of individual rights from legislative incursion. ${ }^{51}$ That view was challenged by legal instrumentalism, which advanced a more 'proactive vision' of the judiciary in creating conditions conducive to market growth and economic expansion. ${ }^{52}$ Instrumentalism was in turn attacked both for its 'materialistic reductionism' and for ignoring law's 'constitutive' capabilities. ${ }^{53}$ The critique of instrumentalism was followed by a 'reformed constitutionalist' approach that proposed an uneasy marriage of the prior two views. ${ }^{54}$ It suggested that the courts both protected property by limiting unreasonable state intervention and moved in private law to inhibit anti-developmental aspects of common law. ${ }^{55}$ This produced, Novak argues, a commitment to 'dynamic individual [capacities and] rights' over a 'common good' in a way consonant with both liberalism and a laissez-faire market economy. ${ }^{56}$ According to these reformed constitutionalists, rights - particularly civil rights protections for property-were 'trumps' for capitalist interests so that judges' decisions in both private and constitutional law facilitated economic expansion. ${ }^{57}$

Now the landscape of argumentation is again transformed. ${ }^{58}$ New research advances the model of a 'well-regulated society'. ${ }^{59}$ This view challenges both liberal claims of unfettered antebellum individualism and instrumentalist emphasis on judicial proactivism on behalf of capitalist interests but does not preclude an early state commitment to economic expansion. In fact, market exchange, though of a regulated sort, and capital accumulation are seen as a primary early policy focus of the state from this standpoint. Regulation in this view enhances market predictability and leverages terms of competition and trade to enable infrastructure creation, social ordering and capital accumulation to flourish. Liberalism's role in this antebellum scenario, despite earlier efforts by other scholars to reconcile it with Whig appeals to a 'common good', appears to be one of a coexisting democratic discourse, at times uneasily reconciled and at others in oppositional tension, contesting the power exercised by the architects of this 'well-regulated' world. ${ }^{60}$ According to this view of a 'well-regulated society', the atomised individual of laissez-

51 As Novak points out, its roots lay in 'limiting doctrines' of due process, vested rights and judicial review (Corwin 1929 and 1911).

52 Hurst 2001; Horwitz 1977; Novak 1996. Portraying law as a reflexive mirror of social processes, instrumentalists contend that law was transformed during the formative era to promote conditions healthy for an industrialising society (Gordon 1984; Novak 1996; Kloppenberg 1993).

53 Gordon 1984; Novak 1996; Kloppenberg 1993.

54 Novak 1996.

55 Ibid.

56 Ibid 23.

57 Ibid 23-26.

58 Ibid; Orren 1991.

59 Novak 1996.

60 Kloppenberg 1993; Vogel forthcoming. To the extent that the atomised liberal individual appears in American history, it is with the rise of the middle class during the mid- to late 19th century. 
faire liberalism in America arose only after the Civil War. ${ }^{61}$ This 'regulatory' view portrays society as 'latticed with social hierarchy', rather than rife with atomised competitors, and committed to pursuing the 'people's welfare'. ${ }^{62}$ Novak suggests that this worldview was a natural outgrowth of a dynamic, common law-based conception of the 'rule of law' ${ }^{63}$ To the extent that he has in mind organic rights rooted in British constitutionalism, this may well be correct. ${ }^{64}$ Certainly, there are other possible explanations as well-notably ideologies of republicanism and cameralism, to name just two. Novak, like Christopher Tomlins ${ }^{65}$ and others, claims quite reasonably that the 'rule of law' afforded the primary 'mode of governance' and 'paradigmatic discourse' for understanding social life in America during the early nineteenth century. He, like Harry Scheiber, ${ }^{66}$ contends that recent scholarship has wrongly read back into antebellum America much of our contemporary liberal worldview, failing to grasp how much American society has changed.

My work builds on Novak's important argument by showing that the rise of market society and persistence of hierarchy were not mutually exclusive. They were, I contend, even more intertwined than has so far been appreciated. Not only the working of markets but also politics and law were, in fact, underpinned by hierarchy. This reinforced the prevailing power of the Whigs who dominated those hierarchies. ${ }^{67}$ We find here, I suggest, a key feature of the social context in which leaders of the new republic set about rethinking political authority. In what follows, I explore this argument by considering three competing hypotheses derived from prior theoretical research outlined above. First, I consider the merits of liberal constitutionalist claims that rights-based judicial activity, particularly civil rights with respect to property, fostered capitalist expansion and opened certain directions for the re-imagining of postcolonial political authority while foreclosing others. Second, I consider an instrumentalist argument that a proactive judiciary nurtured law and economic growth in a context of unfettered markets in ways such that the project of rethinking authority was inevitably coloured by the power of a ruling elite. Third, I explore the contention that a regulatory approach leveraged charters, market participation and terms of trade in the name of a 'common good' so that perceptions of that 'good' and the hierarchical society that it presumed influenced the conception of authority that

61 Novak 1996; Friedman and Scheiber 1988.

62 Novak 1996. Resonant with the republican political traditions touted by historians JGA Pocock and Gordon Wood, this new approach treats the politically powerful legal paradigm of the day as customary cultural development rooted in common law.

63 Central to this legal sensibility were: a focus on man as a social being rather than an isolated individual; a 'relational' theory of rights, a pragmatic, 'pre-Enlightenment conception' of 'the rule of [common] law', and a view of 'the people's welfare' as obtainable through a 'well-regulated society' (Novak 1996).

64 Zuckert 2000.

65 Tomlins 1993.

66 Scheiber 1987a, 1987b; Friedman and Scheiber 1988.

67 It was not until after the Civil War that the inequality that arose during the antebellum years would ripen in America into class conflict between organised labour and capitalists. 
emerged. If one or the other of the liberal interpretations is correct, we might expect a justification of state power, or authority, based at least partly on its sustenance of private ownership, autonomy in its use and a limited state role, especially in terms of economy, as well as a liberating developmental stance of common law. The instrumentalist view suggests acceptance of state power due primarily to its promotion of economic expansion, whose benefits would serve elite interests, through legal change. In the third case, support for the state would likely be claimed on the basis of statist activity on behalf of a 'common good'-however that might be defined.

Looking ahead, patterns analysed in this study suggest that, in ways we shall see, each interpretation of early nineteenth century legal history contributes a unique element to our understanding of authoritative postcolonial governance as it took shape in Boston during this period as well as exhibiting crucial limitations. My argument draws on these prior legal historical interpretations but differs by prioritising institution building and discursive contest within a context of limited local governmental capacity to sustain order. My findings portray a Whig elite whose power is threatened as the franchise is extended and popular democratic politics gains strength. Having lost control of elected office as deference waned, this elite, I suggest, turned its attention to the courts as a venue for pursuing its policy agenda and for imbuing society with its sensibility. ${ }^{68}$ Through the courts, Whig leaders sought to foster a social and cultural infrastructure conducive to industry, civic responsibility and harmony. To do so, they set about articulating a vision of political authority for a new postcolonial world of self-rule. What is significant is that, in seeking to reconsolidate existing contours of power under their leadership, their stance became essentially counter-revolutionary.

Thus, this is a story of the rise of a justificatory framework of postcolonial governance against a backdrop of the post-Revolutionary 'rule of law' in America and a particular conception of freedom, their seemingly paradoxical interdependence with relations of social hierarchy and their roles in constituting the ideational infrastructure for an authoritative postcolonial politics of self-rule. During the antebellum years, then, three projects crucial to establishing a foundation for self-rule were initiated: (1) developing discourses and institutional arrangements of local governance; (2) imagining the postRevolutionary political subject; and (3) articulating an authoritative justification for the role of state institutions, especially law, in social ordering. The second of these is addressed in my article 'Embedded Liberty', which explores the construction, largely through the courts, of a postcolonial concept of the political subject as 'citizen'. ${ }^{69}$ The first is explored in my article 'Dueling Discourses'. ${ }^{70}$ With respect to the third, leaders pondered how to explain why law should be obeyed in a republic, even when at odds with one's own immediate interests, and, even more important, how this understanding might be

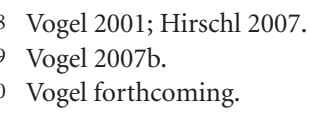


inscribed in the citizen as a subject of power. ${ }^{71}$ How they approached that challenge is the focus of this paper.

\section{POST-REVOLUTIONARY GOVERNANCE AND THE PROBLEM OF POSTCOLONIAL POLITICAL AUTHORITY}

In the years after the Revolution, political leaders in Boston devoted themselves to reestablishing post-independence arrangements for governance. ${ }^{72}$ A primary concern was creating an approach to social ordering. How, they wondered, might political authority be re-imagined? Further, how might it be imbued in citizens? ${ }^{73}$ Jurists sensed that if the new polity was to realise its claim to be one governed by, first, republican and, later, democratic rule, order must rest not on power or coercion but on popular acceptance of governance and on a sense among the people that it was their duty to obey. That is to say, they believed that a vision of political authority consonant with self-rule was needed. ${ }^{74}$

The findings of this study suggest that, despite the 'modernity' of the new republic, the form of authority that emerged was a unique blend of both contemporary 'rationallegal' and traditional 'customary' elements. It linked the imagery of legality with the traditional power that had long accrued to local social hierarchies through time-honoured schemes of household and communal governance. Prevailing discourse of the 'rule of law' provided an ideational template for authoritative normative justification of both rules and the officials implementing them. Recourse by that law to traditional social hierarchies infused that postcolonial authority in America with a customary stabilising social base. ${ }^{75}$ In this activity, the courts played a key part. This paper explores the contours of the new form of postcolonial political authority that was constructed in America, the ways in which it reflected ongoing partisan struggle, and how it was created and justified. I examine how the discourse of the rule of law, the law as written and the institutional practices of the courts contributed to shape that vision of authority as part of a political struggle over what form self-governance would take.

\section{AUTHORITY, POWER AND THE ROLE OF INSTITUTIONS: BUILDING ON A VISION OF THE POLITICAL SUBJECT}

Thinking about power and, more particularly, how it operates in the context of institutions and the state, scholars have recently emphasised the multiplicity of forms

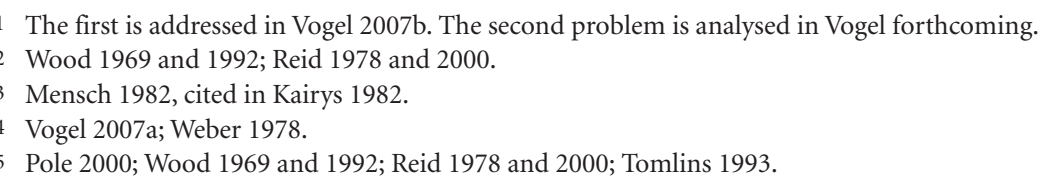


that it takes. ${ }^{76}$ They have also focused on solidarity and duties as part of the 'social' phenomenon of power, ${ }^{77}$ power as 'symbolic violence ${ }^{78}$ and the processes whereby power, especially state power, is produced and then reproduced. ${ }^{79}$ Institutionalist perspectives have pointed to the ways in which webs of cultural practices shape the exercise of power through social action by facilitating some options and foreclosing others. ${ }^{80}$

As a vision of governance and authority began to take shape, some key elements were already in place. A distinctive conception of liberty along with practical efforts to instill it, a repertoire of devolved arrangements for household and communal governance and a well-established discourse of the 'rule of law' all existed. ${ }^{81}$ We also see regulatory practices for licensing, granting charters, pricing and controlling sale of some goods such as milk and alcohol. ${ }^{82}$ These arrangements powerfully leveraged the workings of both society and market exchange, which remained, paradoxically, at the same time, formally 'free' ${ }^{83}$ A good deal of the practical work of local governance was gradually being undertaken by the courts. ${ }^{84}$ Foundations had already been laid in colonial legislatures, the deliberations of the Constitutional Convention and the years of law-based governance under the British. The language and imagery of law-based rule had, by the early nineteenth century, emerged in America as a prevailing one. ${ }^{85}$

Now it was necessary to specify the justification for authoritative rule. The concomitant project of envisioning the nature of the political subject and her or his relation to the sovereign has been discussed in my previous work. ${ }^{86}$ We saw that conceptually interrelated judicial decisions and court practices provided a basis for imagining citizenship in America in terms of a shared performative commitment to liberty. ${ }^{87}$ It was also demonstrated that the courts conceptualised that liberty in ways drawn from common law and consonant with the industry, civic responsibility and harmony required for political stability and economic expansion. ${ }^{88}$ An image of the citizen, then, as someone embedded locally in instituted processes of political membership and social sorting arose

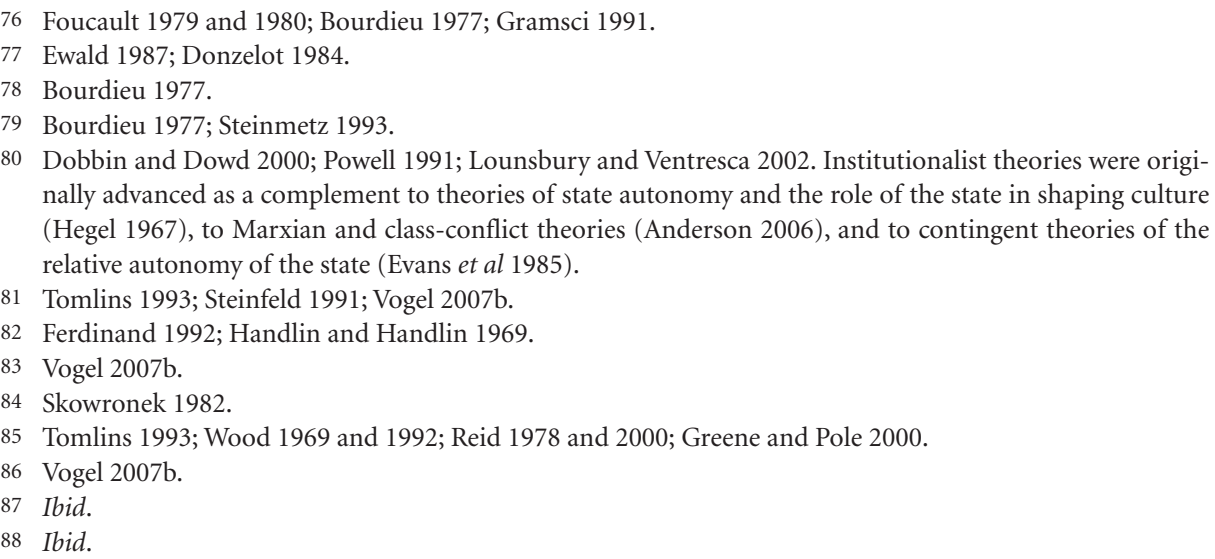


from the courts. ${ }^{89}$ The vision of the political subject that emerged in the courts, we saw, was one of a person formally free-but with options whose contours and conditions were recognised as structurally limited. ${ }^{90}$ As Zuckert ${ }^{91}$ has shown, the political subject of these days was one for whom rights, whether envisioned as the sort accorded by British constitutional tradition or the American Declaration of Independence, were accompanied by duties. That distinctive concept of 'embedded liberty' was consistent with a 'wellregulated' economy and a republican notion of pervasive state action on behalf of the 'people's welfare'. ${ }^{2}$ This represented a continuation of a late eighteenth century development, wherein, as Gordon Wood has shown: 'The traditional covenant theology of Puritanism combined with the political science of the eighteenth century. ... Liberal rationalist sensibility blended with Calvinist Christian love to create an essentially common emphasis on the usefulness and goodness of devotion to the general welfare of the community. Religion and republicanism would work hand in hand to create frugality, honesty, self-denial and benevolence among the people. ${ }^{93}$ Both in judicial decisions and in practical discretionary arrangements for resolving cases, the courts, I have shown, further fostered the reconsolidation of Whig power through law during the 'formative' era of the 1830s. ${ }^{94}$ We have already begun to see, then, that the legality in which justification for a state-based right to command and civic duty to obey would be anchored was constituted not only by formal judicial decisions but also through practices and the exercise of legal discretion by the courts. ${ }^{95}$ It depicted a political subject who was procedurally free but structurally circumscribed in the choices open to her or him.

\section{COMPETING VISIONS OF THE SOCIAL ORDER}

As the courts and community leaders worked to shape post-Revolutionary governance, they grappled with the issue of what type of order to establish. These were years when market forces and industrialisation produced diverse and conflicting interests. Geographic mobility also uprooted community ties and produced the new experience of encounters with strangers. ${ }^{96}$ As this occurred, society, now envisioned as 'well-regulated' by scholars

89 Ibid.

90 Ibid.

91 Zuckert 1994 and 2000.

92 Cameralism drew on an approach to governance harking back to Aristotle which depicted a positive stance of the state toward social change along with growth and assurance of the public good. It is the science of benevolent administration using means of finance, economics and policing. The concept of Commonwealth, which is central to it, emerged from the Italian Renaissance and depicts a state committed to the prosperity and improvement of its people (Small 1909).

93 Wood 1969, cited in Kloppenberg 2000, p 698.

94 Horwitz 1977; Vogel 2007a.

95 Vogel 2007a.

96 Knights 1972; Sellers 1991. 
of that day, such as Joseph Story, ${ }^{97}$ experienced mounting strain. Traditional elites sensed threat as rising markets produced new wealth, though their power nonetheless, some argue, endured to century's end. ${ }^{98}$

As the democratic spirit stirred in the late 1820s and early 1830s, struggle for power surfaced among both workers and the middle class. Contest also arose across social ranks and political parties to appropriate the language of liberty. ${ }^{99}$ Courts, workplaces, churches and schools provided some arenas where this struggle transpired. ${ }^{100}$ In response to fears generated by the post-Revolutionary experience in France, which had ushered in the Reign of Terror, judges, like employers, ministers, educators, philanthropists and other community notables — predominantly supporters of the Whig Party_-moved to highlight the social 'embeddedness', rather than the autonomy, of each person. The sense was that French violence had stemmed from a transformation that turned people out of their stabilising social roles as radically unconstrained individuals. That, in America, each person still had an intact place in the relational webs of everyday life and that priority must be given to sustaining those roles was tacitly or, sometimes, explicitly agreed. ${ }^{101}$ In a sense, the effort was to show that, despite urbanisation, migration and social change, a community still existed-part political and part religious - whose common good one must foster. ${ }^{102}$ Its members shared a common commitment to liberty, though not in the form of unbridled self-interest. The republican ideal of virtue, according to which individuals defined their interests in terms of their perceptions of the common good, had been transformed by the 1830s to signal Whig propriety. Insofar as sustenance of the existing order could be associated with a residual common good, acceptance of structural constraint on procedurally free choices could, however, be reconstrued, thus, as virtue. On this basis, leaders sought to reassert the social, relational and ordered nature of society as their partisans, the American Whigs, envisioned it. ${ }^{103}$

As this emphasis on social roles, social hierarchy and informal control gained strength, it helped reconsolidate the power of employers, patriarchs and other pillars of the community. In response, some among the 'producing' ranks pressed for countervailing freedoms such as the ability to sever an employment relation, the abolition of slavery, and protections against intrusive state policing and supervisory activity over the lives of accused lawbreakers. This was part of a broader partisan struggle between the insurgent

97 J Story 1829; see also WW Story 1851.

98 Orren 1991.

99 Vogel 2007a and 2007b.

100 Hegel 1956 and 1967; Taylor 1977 and 1985; Kelly 1972.

101 Sellers 1991; Warren 1931.

102 Sellers 1991.

103 Howe 1979. At a time when Georg Hegel was recognising the power of middle-level institutions and cultural practices to support sittlichkeit, or harmonious and ethical living, the Americans either borrowed or arrived independently at a similar idea (Taylor 1977). 
Jacksonian Democrats and the American Whigs. ${ }^{104}$ The nature and symbolic power of the imagery of liberty, in particular, gradually crystallised as a focus of debate. This occurred as capacities of language to shape social reality produced a contest, as it had earlier in France, to appropriate the image of liberty to partisan ends. ${ }^{105}$

As Democratic 'citizen-workers' in America resisted Whig power, they took inspiration from Enlightenment ideas. Thomas Jefferson, from whom much post-Revolutionary political thinking originated, defined self-interest in contrast to Locke's conception of virtue. As a result, he envisioned a society where men's inner moral compasses would prevent them from oppressing one another. Jefferson decried putting personal interests before those of the community. 'Self love', he claimed, 'is no part of morality. ... It is the ... antagonist of virtue ...' ${ }^{\prime 06}$ Jefferson embraced civic virtue along with individual rights but always coloured both with the Christian ideal of universal benevolence. In the decades after the Revolution, Shalhope argues, 'the emphasis placed on equality in revolutionary rhetoric stimulated great numbers of previously deferential men to question all forms of authority and to question distinctions of every sort'. ${ }^{107}$ He observes that the transformations taking place during the decades just after the war were 'so complex and indeliberate ... that most Americans were unaware of the direction such changes were taking them and their society'. 108

According to Shalhope, ' $\mathrm{t}$ ] he commitment [of Americans] to republicanism allowed them to continue to imagine themselves as members of a virtuous, harmonious organic society long after the ... foundations of such a society had eroded' ${ }^{109}$ He concludes: 'It allowed-even impelled-men to view themselves as committed to the harmony, order, and communal well-being of a republican society while actively creating an aggressive, individualistic, liberal and materialistic one.'110 He suggests: 'Ironically, then, republicanism provided the fertile seedbed within which the individualistic liberalism of the nineteenth century took root. ${ }^{\prime 11}$ As to how this change took place, Shalhope states: 'The presence of an ideology as powerful as republicanism fostered an unconscious tendency among the dominant majority of Americans to make reality amenable to ideas, and ideas to reality, so as to create an integral worldview credible enough to foster a collective as well as an individual sense of identity and security.' ${ }^{112}$ Yet, Shalhope presumes a consensual shift while my forthcoming work suggests a more contested one. ${ }^{113}$

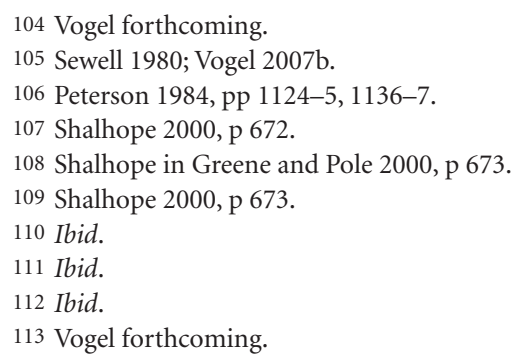


Enlightenment ideas appear to have been received in discursive forms such as the French Declaration of the Rights of Man or Kant's What is Enlightenment? These were subsequently absorbed in America into religious and cultural normative visions. This occurred most notably through Unitarianism and, shortly thereafter, the New England Transcendentalist movement. ${ }^{114}$ Culturally, what appears to have been received from this source is a sense of the inherent dignity of each person, strong individualism and a political language of natural law rather than constitutionally derived rights in the context of a law-based state. ${ }^{115}$

Despite these eruptions of contestation during the 1820s and 1830s, it was the postFederalist, Whig vision of society, committed to the 'common good' and grounded in common law rather than liberalism, that dominated American legal discourse into midcentury. ${ }^{116}$ The often under-appreciated intensity and coherence of this struggle is revealed, in part, by strong parallels in developments under the American Whigs in labour law, criminal law and political economy. ${ }^{117}$ Thus, my work, while acknowledging the powerful prevailing 'rule of law' discourse, queries interpretations of it as universal or monolithic. Instead, I highlight contestation in the arenas of language and institutionbuilding as part of a process of constituting disparate images of the 'imagined' American community on the part of competing social groups. ${ }^{118}$

Despite Democratic resistance, this Whig vision of 'embedded' liberty, rather than 'laissez-faire', continued to flourish through the 1840s. ${ }^{119}$ Thus, we see the project of constituting a discourse and practice of authoritative governance and contest over the nature of 'freedom' as places of struggle between the oppositional discourse of liberal Jacksonian Democrats and that of the incumbent and more privileged Whigs.

\section{RECONSTITUTING AUTHORITY: DRAWING ON DISCOURSE AND SOCIAL HIERARCHY}

When American jurists and politicians set out to craft a postcolonial conception of political authority, or authoritative justification for governance, it was, in their mind's eye, to be rooted in a 'rule of law'. While voters shaped electoral results, political leaders, once elected, were expected to avoid acting in arbitrary, capricious or even overtly selfinterested ways. ${ }^{120}$ This complemented the principle, dating back to Magna Carta of

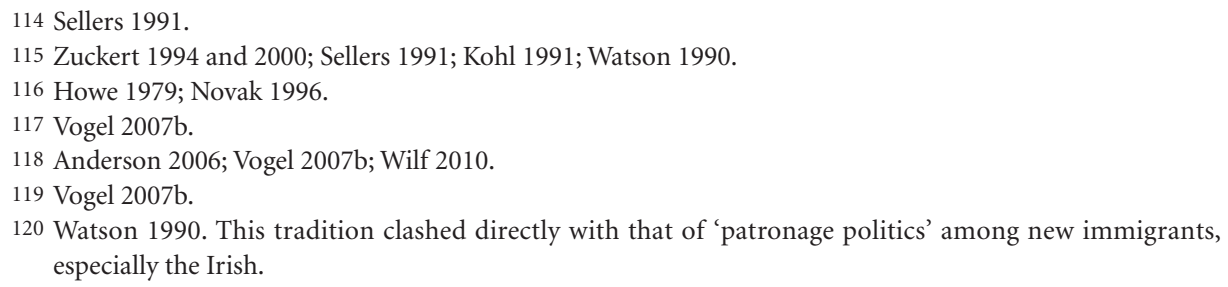


1215-limited as that agreement has been shown to have been - that even a queen or king must be bound by the law. ${ }^{121}$ This principle, it was believed, should extend no less to self-rule than to a monarchy. ${ }^{122}$ In fact, absent a monarch's traditional claim on compliance, lawfulness itself, along with popular electoral support, increasingly appeared to be the best means for justifying a regime of self-rule. ${ }^{123}$

Commands and rules must now, it was thought, demand compliance on account of their basis in law. ${ }^{124}$ Thus, the United States, like many subsequent republics, moved toward a vision of authority that was of a primarily rational-legal sort. ${ }^{125}$ In that the 'rule of law' was, however, now introduced into governance based on popular sovereignty, there was an inherent tension in the polity and, consequently, in political authority as well. ${ }^{126}$ It was one in which 'law rule' and 'self-rule', both foundational claims of emergent democratic governance, would often stand historically at odds. ${ }^{127}$ However, this conflict was no greater in America than in other republics and less so than in many. Each republic would, however, move to resolve the 'law rule' versus 'self-rule' tension in its own way. How they did so affords us insight into the kind of democracy each would become.

In ways that seemed prescient, local leaders recognised that ideology alone, unsupported by participation in integrative social networks, even transformed ones, could prove an unstable basis for order. The Jacobin excesses of the Terror in France had seared their imaginations. ${ }^{128}$ Local politicians sensed that, along with laws, modern political subjects-lacking, now, the personal allegiance and customary obeisance to traditional authority - required another source of normative and behavioural guidance. They sought consciously to nurture it through the social control that comes with a secure place in the web of customary roles and routines of the quotidien. ${ }^{129}$ Historically, rulers' powers were

121 Bingham 2011.

122 Mill 1975.

123 Sellers 1991; Tomlins 1993.

124 Tomlins 1993; Weber 1978.

125 Weber 1978, p 215. According to Weber, rational-legal authority locates the basis of its legitimation in the fact that the offices of its leaders are specified in law and its rules are enacted in law.

126 In his article 'Law's Republic', Frank Michelman (1988) probes the tension between 'law rule', according to principles and rules (especially Constitutional ones) that stand above the sway of popular opinion, on the one hand, and self-rule (also known as popular sovereignty) by a people or its representatives through the electoral and legislative process, on the other.

127 Michelman 1988; Vogel 2007a; Bingham 2011.

128 Kloppenberg 2000.

129 This belief in the importance of social rank and the authority of household and workplace, so popular in the early 1800s, finds extensive theoretical and empirical support in Talcott Parsons' work Politics and Social Structure (1969). In it, Parsons describes a state he calls anomie in which large numbers of individuals are lacking integration with stable institutions which are necessary for their personal stability. According to Parsons, these institutions, such as family, church, school and economy, are nothing more than clusters of independent role patterns that prescribe appropriate behaviour. Their significance lies in the fact that they 'structure value orientations' and 'enable the internalization of value systems into the personality'. Social roles thus provide the basis for an orientation to action and for socialisation that are conducive to social stability. 
bolstered by the social control exercised by hierarchies of traditional authority - whether in the context of family, the middle-level institutions of the workplace or community. ${ }^{130}$ Many thought that, in France, mobs had taken to the streets not as a result of extremism, but because they were displaced from those stabilising relationships and routines by the upheaval and transformative effects of the Revolution. ${ }^{131}$ If political order could be had, networks of social roles and middle-level institutions must, it was believed, play a vital part in the project of control. ${ }^{132}$ Because the binding forces of religious community, normative consensus and deference had eroded noticeably, the formative and constraining elements of social hierarchy and of one's social position assumed even greater importance. ${ }^{133}$ The alternative, it was feared, was to see the social order cut loose entirely to produce radically uninhibited individuals in America whose violence might equal that of the French. A sense of the appropriate nature and role of these hierarchies was being articulated, partly, in the courts. ${ }^{134}$

The situation and capacities, both political and legal, of persons inhabiting this postRevolutionary polity had to be clarified. Initially, American republicanism viewed political membership in terms of privileges and responsibilities. ${ }^{135}$ Exercising these capacities involved choices, among other things, regarding social order, civic discourse and the vote. As a matter of accepted pre-Revolutionary legacy from the British, behaviour was presumed, as we have seen, to be normatively guided by the 'rule of law'. ${ }^{136}$ Yet, what the impact of self-rule would be, especially when personal interests ran counter to the law, was unknown. One remarkable feature of the documents of that day is their sense of wondrous uncertainty as to whether self-rule, as part of the American governmentality of 'policing', or ordering, could survive. ${ }^{137}$ As a first step, leaders responded to this situation by moving to envision the political subject, or subject of power, anew. In ways consonant with sittlichkeit - Georg Hegel's conception of ethical life-that was then being touted in Europe, the political subject was re-imagined as one enmeshed in the guiding and supportive fabric of the informal hierarchies, particularly those of family and work, that were cornerstones of traditional power and the activities of everyday life. ${ }^{138}$ It was hoped that these could structure and, consequently, modulate the lives and political activity of their incumbents. Each social tie, such as householding, parenting, employment, property ownership, tax payment, borrowing and voting, afforded society an opportunity to leverage and shape the behaviour, normative stance and freely made

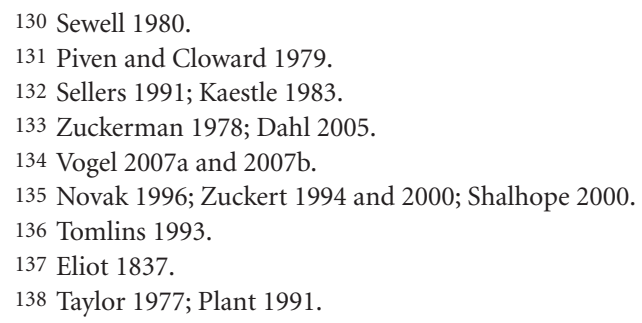


choices of its members. This occurred through processes of socialisation, classification, social sorting and, especially, normalisation. The agenda was to promote, thereby, orderly, responsible and harmonious living.

\section{THE SOCIAL IMAGINARY OF CITIZENSHIP: A COMMON COMMITMENT TO LIBERTY}

To rethink authority, one had first to envision the postcolonial political subject. In America, following France, the subject of power was envisioned as 'the citizen'. ${ }^{139}$ What emerged was a dual emphasis on the choices of formally free persons, on the one hand, and political efforts to re-embed them socially, on the other . In 'Embedded Liberty', I explored how a vision of the political subject as 'citizen' took shape in antebellum America and the role that law and the courts played in that process. ${ }^{140}$ I showed that 'citizenship' emerged as a constructed political identity. It established the basic parameters of the civic behaviour the new nation sought to foster. This view of the political subject as citizen was anchored in a common commitment to 'liberty'. In contrast to prevailing theoretical developments in philosophy and theory, the liberty it embraced was, I showed, of neither a fully autonomous nor a 'laissez-faire' sort but rather of a particular 'embedded' kind. In fact, we cannot help but wonder if these initiatives of the American Whigs, which resonate so compellingly with the sweeping state activism of Austrian and later French cameralism, might not be working to set in place just the sort of social arrangements that scholars from Immanuel Kant to Adam Smith were resisting. This innovative focus on 'liberty' emerged, I suggest, as a basis of community for a diverse country of immigrants who shared neither ethnic nor sanguinary ties. Nor did they constitute by any other 'natural' means a 'demos'. What this common commitment to liberty created was an ideational basis for community—or an early 'social imaginary'. ${ }^{141}$ This model of citizenship appears, perhaps unconsciously, to have been a secular adaptation of the model of a religious community. ${ }^{142}$ The idea of an imagined community' was one that would later be echoed by other nations and also by the European Union in its commitment to citizenship in a community focused on rights. ${ }^{143}$

\footnotetext{
139 Vogel 2007a and 2007b.

140 Vogel 2007b.

141 Vogel 2007b; Taylor 2004.

142 Nelson 1981.

143 Anderson 2006. Citizenship has been defined in the scholarly literature variously as a status (Marshall 1964), an endowment of rights (Soysal 1995) and an instituted process (Somers 2008). In pre-Jacksonian America, citizenship appears initially to have involved a quasi-contractual notion of status that implied privileges and duties rather than more purely legalistic claims of rights. The role of citizen was a contingent affair where political membership and liberty were granted while tolerance of social inequality and constraint on 'free' choices were simultaneously expected.
} 
Absent a highly developed state apparatus to inculcate the habits of mind and action of this 'citizenship', labour markets and other institutions of civil society were relied upon in America and, to a lesser degree, in Europe as primary instruments for incorporating and socialising citizens. ${ }^{144}$ Thus, as a notion of the 'citizen' took shape in postcolonial America, both the 'rule of law' and personal embeddedness in social institutions played crucial formative parts. ${ }^{145}$ They shaped and supported a nascent political subject struggling to create a better life amidst rising economic inequality. ${ }^{146}$ What was emphasised, especially, as a means to imbue civic awareness and responsibility was education in all its many forms. The aim was to render the behaviour of citizens constructive, responsible and benign. ${ }^{147}$ The habits of mind to make self-governance viable must, it was believed, be inculcated both formally and informally through society's institutions including schools, family, churches, cultural groups and, especially for adults and new immigrants, through the workplace and the courts. ${ }^{148}$ Fears abounded as to what could be expected in a free society from persons who either did not participate in the web of membership or colluded within it to foster particular interests - that is, from the unaffiliated, on the one hand, and from faction, on the other. ${ }^{149}$ New immigrants, who arrived without either social connection or experience of American political values, were especially feared. ${ }^{150}$

Beyond the challenge of cultivating a responsible populace, the tasks of weaving a new social fabric, incorporating new immigrants and voters into it, stabilising that new society, and justifying state actions so as to preserve order without resort to coercion presented the polity with critical dilemmas. Dominating the minds of both notables and men of 'the middling interest' alike was the potential for a threat to property and social order that might arise where a populace used their political right of the franchise to attempt to remedy inequality. For these reasons, in the process of constructing a canopy vision of postcolonial authority to justify governance and elicit compliance, the discourse of a 'rule of law' was bolstered, following the courts, by consciously interweaving it with very traditional mechanisms of social control and governance situated in social hierarchy. Such an approach meant, however, that the implementation of authority reinforced vestiges of rank from the pre-Revolutionary social order. This acted, in effect, as a counterrevolutionary force. It reduced the socially transformative effects of the American War of Independence, which were already quite limited. ${ }^{151}$ I turn now to consider more fully the context in which this challenge was addressed.

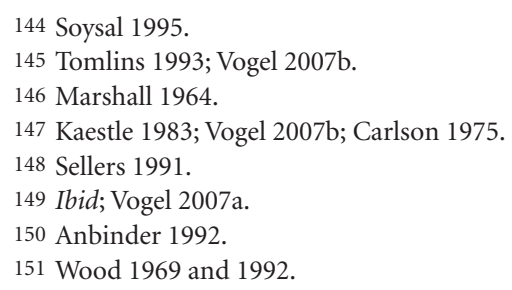




\section{SOCIAL DISORDER AND RISKS TO THE SECURITY OF PROPERTY}

Whether one interprets law during this period from a constitutionalist, instrumentalist or regulatory perspective, it is clear that governance faced a significant problem of social disorder. ${ }^{152}$ Political leaders sought to consolidate authoritative local rule largely because they feared a class-based sentiment that was growing increasingly assertive. Industrialisation and market development also contributed to conditions that could jeopardise the republican polity. This was because, as economic growth advanced, so did inequality. Wealth grew more concentrated. ${ }^{153}$ This increasingly 'unequal distribution of wealth' was denounced by historian George Bancroft as cause for 'feud between the house of Have and the house of Want'. ${ }^{154}$ Mounting inequality meant that the proportion of those living in poverty mushroomed. In accounting for concentrating wealth alongside spreading poverty in the cities, some commentators blamed what they termed the expropriation of the fruits of the 'producing many' by the 'exploiting few'. ${ }^{155}$ Pointing to speculators and industrial capitalists as the cause of growing inequality, Samuel Clesson Allen urged political resistance. ${ }^{156}$ Through 'universal suffrage', Allen argued, 'the people can now ... [reclaim what is their due through political means]'. ${ }^{157}$

For Boston's elite families, the suggestion that voters might use the franchise to restructure or abolish legal provisions relating to private property gave voice to one of their deepest fears. Awareness of the central role played by private and exclusive ownership of property in accumulating wealth was strong. Allen observed that to 'renovate society you ... [can] begin with its economical relations ... [which shape society] more than government, more than morals, more than religion'. ${ }^{158}$ He argued that prevailing arrangements had 'divided society into two classes, enabling "accumulators" to impoverish "producers"”. ${ }^{159}$ Particular venom was reserved for those who prospered by purely specu-

152 Sellers 1991; Monkkonen 2001.

153 Pessen 1967, pp 1020-31.

154 Schlesinger 1945, pp 159, 162-3. Rejecting the argument that property-based Lockean liberalism constituted the intellectual foundation of American democracy, Bancroft, under the influence of the German Romantics, turned instead for its political inspiration to the Inner Light of Quakerism. Analysing capitalist transformation from the standpoint of this Inner Light, Bancroft exhorted workers to reconnect with that spirit and to cast their lot with Jacksonian democratic opposition to the cupidity of privilege (Sellers 1991, p 341). In Bancroft's eyes, as in others', far greater danger lay in monopoly and the inequality that it produced than in the combinations of working men (Sellers 1991, p 341).

155 Sellers 1991, p 338.

156 Ibid, 339.

157 Ibid, 339.

158 Ibid, 339.

159 Ibid, 339. Samuel Allen's distinction between 'productive' and 'unproductive hands', which had appeared earlier in Adam Smith's Wealth of Nations in 1776, honed in on the key social cleavage of the day. By imputing to the producers of goods a status as society's most worthy members, Allen echoed a popular view that use-value should accrue to its creators who produced that value through labour. 
lative means. ${ }^{160}$ Thus, Allen and others pointed to patterns in the ownership and means of acquiring property as a source of deepening social conflict. In his view, the route to reform lay in its reconfiguration. Thus, deepening inequality and widening poverty were emerging as major sources of tension and conflict. Spreading deprivation raised the spectre of popular efforts to improve living conditions by means of the vote or, if not, perhaps through violence.

\section{THE TRIPLE THREATS OF FACTION, DISAFFILIATION AND CRIME}

Concern among the privileged also stemmed from fear of three other distinct but interrelated political potentialities-faction, disaffiliation and crime. In The Social Contract, Jean Jacques Rousseau observes that faction, wherein individuals, rather than acting autonomously, collude to promote a narrow private interest, undermines and distorts democracy. In Boston during the 1830s, the workingmen's parties and the unions, which had been newly established by the militant labour movement of these years, presented just such a threat. By the 1830s, between 20 and 33 percent of workingmen in the urban northeast were trade union members. ${ }^{161}$ They mobilised for improved working conditions. Between 1833 and 1836, more than 150 strikes wracked the American urban north-east. ${ }^{162}$ These strikes won a ten-hour day. ${ }^{163}$ What was new and ominous from an elite standpoint was that, for the first time, unions in striking trades received financial backing from their brethren in non-striking trades through the General Trades' Union. A nascent sense of American working class consciousness simmered. ${ }^{164}$

If workingmen's mobilisation sparked concern, so too did the unorganised ranks of transients, marginals and otherwise disaffiliated abounding in the cities. This took on added urgency amidst rural-urban migration because of the new phenomenon it produced of frequent encounters with 'strangers', who, in contrast to the situation in village or small town life in the past, were completely unknown. This amplified feelings of insecurity. Each of these 'non-productive hands', of which paupers were the most pressing case, was feared as consuming more than he produced and, thus, retarding economic expansion. Unskilled service workers such as day labourers and seamen; social marginals

160 According to the popular wisdom of the 1830 s, the most powerful 'instruments ... [advancing] accumulation' and concentration of wealth were 'currency, ... credit, and the interest of money ... [though] they [themselves] produced none of the objects of wealth' (Sellers 1991, p 339). Through speculation and financial manipulation, great fortunes were amassing 'in stocks and bonds and notes and mortgages' while the onerous costs of the paper currency then in use fell on 'the productive class and not on the capitalist' (Sellers 1991, p 339).

161 Sellers 1991, p 338.

162 Ibid.

163 Dublin 1979; Wilentz 1984.

164 Sellers 1991, p 338; Montgomery 1979. 
such as widows, orphans and spinsters; and, finally, the unemployed were all of special concern. ${ }^{165}$ The unskilled and unemployed aroused apprehension, in addition, because they were believed to lack the habits of mind conducive to social order.

As society reflected on the political danger presented by factions and the unaffiliated, the waves of immigrants who were arriving from Europe evoked further anxiety. ${ }^{166}$ Most political leaders believed that their arrival was inevitable but wondered how they should be treated. Industrialist Abbott Lawrence asked rhetorically if they had 'the needful discipline to make them safe associates in maintaining our system of government'. ${ }^{167}$ Amidst vibrant antebellum politics, the question was into what political fabric the newly enfranchised and, especially, recent migrants could be woven and what normative scheme could guide their behaviour in a self-governing society. ${ }^{168}$ Immigrants posed a threat, many believed, not just because they were different and knew little of American ways but because they were prone to crime. ${ }^{169}$ Fear of immigrants was amplified during these years by rising crime, especially homicide, and rioting. ${ }^{170}$ These sentiments found statistical support in most cities, including Boston, where immigrants were alleged to 'perpetrat[e] crimes far out of proportion to their numbers' ${ }^{171}$ According to the press, immigrants were also causing growth in the numbers of paupers. ${ }^{172}$ Many attributed the crime-prone nature of new arrivals to an alleged European practice of 'dumping' convicts and the poor in America. ${ }^{173}$

Faced with such influx, community institutions such as churches, schools and the courts as well as workplaces were explicitly turned to the task of promoting cultural assimilation. ${ }^{174}$ Judges worked to distinguish ne'er do wells from worthy persons who

165 Sellers 1991.

166 Anbinder 1992; Higham 1955.

167 Lawrence 1856, p 258.

168 Ibid; Kaestle 1983; Carlson 1975.

169 The Charlestown Advertiser in Massachusetts reported that 'forty of forty-one persons arrested' in a given week had been 'born abroad' (21 November 1855, cited in Anbinder 1992, p 107). A Know Nothing newspaper in Albany asserted that immigrants were 'ten times more likely to be arrested than native-born citizens' and that immigration represented 'the chief source of crime in this county' (Albany State Register, 1 October 1855, cited in Anbinder 1992, p 108).

170 Monkkonen 2001; Anbinder 1992, p 107.

171 Anbinder 1992, p 107. Such assertions, of course, neglect entirely the question of whether immigrants were the victims of selective law enforcement and so more likely than others to be arrested-though not necessarily more prone to perpetrate crimes per se.

172 Anbinder 1992, p 108. Know Nothings alleged that the character of foreign immigration, especially the Irish, had changed. While earlier immigrants were seen as industrious and frugal, later ones appeared to be 'simply too lazy to work' (Cincinnati Dollar Times, 14 September 1854).

173 'From the "refuge of the oppressed", we have come to be the great Botany Bay of the world', lamented the Youngstown True Observer (21 February 1855). In Britain, it is known, for instance, that the 'emigration of 5,000 Irish paupers per year beginning in 1847' was funded by the state. In Ireland, 'landlords sent ... 50,000 destitute tenants to America' between 1845 and 1855. In Germany, almshouses were cleared by sending occupants to America (Anbinder 1992, p 108).

174 Carlson 1975; Kaestle 1983. 
had simply taken a misstep and to restore the offender to a path of harmony and industry. ${ }^{175}$ Assimilation highlighted the shared performative commitment to 'liberty' to which we have already referred as the image of the unity that society sought to foster. ${ }^{176}$ Because no ethnic or racial 'demos' existed in America, national identity in an imagined community' came to be understood and imbued largely through a common culture. Thus, cultural assimilation of immigrants, along with deviants of any sort, was prioritised. Attention was self-consciously lavished on articulating that culture. ${ }^{177}$

\section{ELITE FOCUS SHIFTS TO THE COURTS AS A FORUM FOR POLICY}

In this context of structural change and an extended franchise, the stirring of popular politics produced anxiety among the affluent as to what the future might hold. As Jacksonian Democrats gained political ground with respect to the Whigs, their ideology, which grew initially from roots in a benign Jeffersonian trust in the virtue of the common man, assumed a new, more complex tone. As late as 1832 the New England Artisan newspaper had spoken of a political tradition of deference that ceded electoral dominance to an American 'aristocracy who control all the political parties of the day'. Yet, as the 1830s unfolded, historian George Bancroft began to observe a Jacksonian sensibility that touted a 'spirit in [every] man ... that places ... [him] in connexion with the world of intelligence and decrees of God'. ${ }^{178}$ Because such a 'sentiment ... [was believed to] exis[t] in everyone, ... [capacity for political participation gradually came to be viewed as universal and extending beyond] the privileged few'.${ }^{179}$ Bancroft, echoing Rousseau, drew what was, for elites, the unsettling conclusion that this produces 'common judgment in taste, politics and religion [that] is the highest authority on earth'. ${ }^{180}$ Among members of the Whig elite, rhetoric such as Bancroft's epitomised their deepest anxieties about the potential for transformative change of an extended franchise. These worries were only partially abated by movements for reform and temperance taking shape in the cities.

175 Vogel 1999. New York Know Nothing Daniel Ullmann articulated their reasoning when he argued that 'where races dwell together on the same soil and do not assimilate, they can never form one great peopleone great nationality' (Anbinder 1992, p 107). If Americans did not manage to forge 'one great homogeneous race', the Know Nothings contended, social division would destroy the nation (ibid; article in Hartford Courant, 1856).

176 Vogel 2007b; Anbinder 1992.

177 Sellers 1991.

178 Ibid, 341.

179 Ibid.

180 Ibid. 


\section{CULTURAL NORMALISATION AND THE 'AMERICANISATION' MOVEMENT}

One fear, as we have seen, was that the political equality provided by the franchise would be seized upon by the populace to pursue material equality. This concern was vividly expressed by Whig educator Horace Mann, who pointed to the danger of popular desires for greater equality. ${ }^{181}$ Highlighting socialist gains in Europe, Mann argued that nearly universal suffrage in Boston meant that 'nothing but mere popular inclination lies between a community of power and a community of everything else ... [ie, property]'. ${ }^{182}$ As an antidote, Mann proposed to establish public schooling. ${ }^{183}$ Warning of the potential consequences of suffrage for property arrangements, Mann won support from taxpayers to finance free schools as a 'barrier against ... those propensities [for change] ... which our institutions [might otherwise] foster'. ${ }^{184}$ Mann's embrace of public schooling stemmed from a belief, earlier expressed by Benjamin Franklin, that the only road to harmony in America lay in the cultivation of cultural sameness or 'homogeneity'. ${ }^{185}$ Education, he argued, was the surest means to that end.

Absent a demos, education emerged as the essential crucible in America for forging relations of citizenship. In this project, the courts too, along with the schools, played a key formative role. Thus, the middle-level institutions of which Foucault speaks were selfconsciously introduced into the process of assimilation. Courts became 'places' to apprise defendants of social rules and to communicate them to the community more broadly. However, in the courts, the process of socialisation also increasingly relied, in ways we shall see, not only on the state's coercive power and the discursive imagery of the 'rule of law' but also on the socialising power of the web of social control represented by the middle-level institutions of family and work. During the Jacksonian era, a conscious effort was made by Whig politicians, educators and ministers to foster cultural homogeneity as a basis for national identity and civic commitment. ${ }^{186}$ This cultural movement came to be known as the 'Americanisation' campaign. ${ }^{187}$ Its sponsors hailed mainly from relig-

181 Cremin 1980, p 117.

182 Mann 1867, pp 143-88.

183 Kaestle 1983. Mann's readiness to play on the fears of the propertied elite regarding the potential excesses of both the restive democratic masses and their representatives in the legislature led Ralph Waldo Emerson to parody the message of the school campaign in the words 'you must educate [the masses] ... to keep them from our throats' (Atkinson 1840, pp 458-9, cited in Sellers 1991, p 368).

184 Norton 1986, p 82.

185 Kaestle 1983; Smyth 1905-7.

186 Carlson 1975, p 41. The essence of that shared identity, we have been told, was individual freedom ... [conceived of in ways consonant with] the Protestant religion, middle class [orientation to] society and a republican form of government' (Carlson 1975, p 41). While much was said at Brook Farm and elsewhere about freedom, the conception actually espoused by officials appears to have been the one articulated in the courts, which I have termed 'embedded liberty' (Vogel 2007b).

187 Carlson 1975. 
iously oriented New England and, in particular, from Protestant Presbyterian stock. ${ }^{188}$ They touted schools, above all, as places to instill cultural 'homogeneity' as a bedrock for a common political identity. ${ }^{189}$

The 'Americanisers' sought to distinguish America from Europe as 'a land of freedom, equality and opportunity'. ${ }^{190}$ Many believed that a common national culture would help reduce strife. Drawing on a self-consciously devised political culture, 'a unique religiopolitical identity' was fostered that was committed to liberty. ${ }^{191}$ Because common socialisation was so crucial for cultivating a culturally based political identity, Whig reformers concluded by the 1840s that the informal efforts of parents and communities were not enough. ${ }^{192}$ To instill not only a commitment to liberty but also the self-control to exercise it responsibly, informal efforts must, it was thought, be supplemented by formal institutional means. It was this that prompted a groundswell of support for the founding of public schools for universal education in America. ${ }^{193}$ Yet, parents remained an important part of the picture. Highlighting the part played by parents in instilling productive and responsible habits of mind, Mann opined that parents 'who refuse to train up children in the way they should go, are training up incendiaries and madmen to destroy property and life'. ${ }^{194}$ Because American culture was unfamiliar to immigrant parents, Mann claimed, their 'children must be gathered up and forced into school'. ${ }^{195}$ While the first American public schools educated children into habits of productivity and responsibility, churches emphasised virtue and harmony, and the courts inculcated an understanding of law, of a particular customary sort as we shall see, and pressed for social reformation of adults, especially immigrants. ${ }^{196}$ Thus, in a way complementary to the power of 'rule of law' discourse, 'Americanisers' relied on the socialising power of the regulatory regimes of society's institutions to inscribe the code of libertarian commitment in the citizen as subject of power.

188 Ibid, 41; Sellers 1991.

189 Carlson 1975, p 41.

190 Ibid, 42.

$191 \mathrm{Ibid}$, 44. The main enemies of American liberty, it was suggested, were the great monarchies of Europe and, especially, the Roman Catholic Church whose clergy were widely thought to have been deployed to America by European royalty to subvert the new nation (Carlson 1975, p 44).

192 Anbinder 1992; Kaestle 1983.

193 Kaestle 1983.

194 Norton 1986, p 82.

195 Ibid.

196 This approach was consonant with important new theorising by German Idealists who emphasised the role of middle-level institutions as a source of guidance and socialisation supportive of ethical life (Hegel 1956 and 1967; Taylor 1977). Such work eschewed a vision of clear boundaries between state and civil society for one that saw them interpenetrated and becoming partners in a project of social control (Hegel 1956 and 1967). It was in these years that German Idealist thought blossomed in the New England Transcendentalist Movement. In that movement the writers Ralph Waldo Emerson, who embraced the influence of Immanuel Kant, and Henry David Thoreau played leading parts. 


\section{SHIFTING ROLE OF THE RULE OF LAW: FROM SUBVERSION TO COUNTER-REVOLUTIONARY INFLUENCE}

Even as the socialising power of society's institutions was acknowledged, there was recognition that the new republic, already consolidated at federal and state levels, must articulate a basis for public governance at the local level to oversee social ordering and civic action. Such local governance would need to be suited to an urbanising, mobile and increasingly diverse society. For the Whigs, the project of adapting the state's juridicopolitical power to self-rule required a vision of postcolonial authority, or ideology of justification, and decisions about how it could best be inculcated. Like many political changes of that day, the project to justify non-coercive, yet authoritative, use of local public power was consciously undertaken. Leaders built on ongoing efforts to imagine anew the subject of power for a world of republican and, then, democratic rule. As the justificatory framework for local rule developed, it drew both on the discourse of a 'rule of law' and on the traditional influence of social hierarchies as sources of institutional support and control.

Many historians ${ }^{197}$ have noted that the experience of having lived under British colonial rule continued to shape American civic and political life after the Revolution. One primary consequence was the powerful legacy of the common law. ${ }^{198}$ Though equally important, fewer have remarked on the tradition of capacious discretion that was also inherited in that law's implementation. ${ }^{199}$ Pizzorno has argued that the common law introduced a closer link between law and politics than is found in the Roman-Dutch law of the European continent. ${ }^{200}$ Due to the British colonial legacy in America of emphasis on the 'rule of law', Reid argues that acts by the British colonial administration that violated colonists' understanding of lawfulness, such as taxation on tea without representation in the body imposing the duty, billeting of soldiers in private dwellings, or searches that violated the privacy of the home, rankled with particular intensity and fanned pre-Revolutionary militancy. ${ }^{201}$ This was because such actions violated American understanding of the 'rule of law'. Reid argues that what was distinctive about American colonialism was that, compared to, say, Ireland, Britain governed more as she did her own citizens at home. ${ }^{202} \mathrm{He}$ suggests that this was due to America's greater distance from England. This created, he claims, a need for self-sufficiency in decision-making for longer

197 Including Reid 1978 and 2000; Wood 1969 and 1992; Bailyn 1967; Greene and Pole 2000; Pole (1962, 1979 and 1983).

198 Tomlins 1993; Novak 1996.

199 Galligan 1990; Weber 1978.

200 Alessandro Pizzorno, personal communication, 1985.

201 Reid 1978. According to Dicey (1982), the 'rule of law' implied at a minimum: (1) universal applicability of law, (2) formal procedural equality before the law, and (3) prohibition on the making of ex post facto law. 202 Reid 1978. 
periods of time than in Ireland, which lay closer to England. Because of the great distance, America was also less of a proximate threat.

Yet, paradoxically, by the early 1800s, the same common law that had served as a subversive force to spark revolution had been challenged as both a colonial holdover, and thus of questionable legitimacy, and as a form of expost facto law. It was argued that only after a judge had spoken could one be sure if an offence had been committed. The capacious discretion afforded to judges under common law was contrasted with what were seen as more clearly specified codes of the Roman-Dutch law. The common law's highly technical forms of pleading, which required the costly assistance of a lawyer, were also believed to restrict advice of counsel to the affluent. The incognoscibility of the common law was especially problematic, it was suggested, for the average man who was effectively denied access to justice. ${ }^{203}$

Such resentment of the common law gave rise by the mid-1830s to a codification movement that sought to replace the common law with Roman-Dutch style codes. The aim was to heighten the influence over law of the popularly elected legislatures that enact the codes. This would, among other things, reduce the discretionary power of judgesmany of whom were rightly seen as more attuned to an elite sensibility than were the elected legislative bodies. ${ }^{204}$ Ultimately the codification movement failed, though its adherents did secure production of summary digests of law and key legal decisions as a compromise.

Despite popular protest surrounding the common law, the imagery of a 'rule of law' remained sufficiently powerful that during the 1830s local political leaders turned to it and relied, once again, on it in their efforts to consolidate postcolonial local governance and order. These leaders, mostly still from elite families, turned to the courts as a forum for outlining, through their judgments and practices, the contours of the nascent order and the nature of its citizens. Recognising that an extended franchise and the decline of deference had greatly diminished their control over electoral outcomes, especially in cities, Whig politicians and their elite brethren focused their attention on the courts as a venue for their political agenda. ${ }^{205}$ In the courts, they found a theatre that was partly insulated and less vulnerable to the inroads of popular politics. Not only were judges appointed rather than elected, but judicial selections were made by state officials who were drawn heavily from among their privileged ranks. ${ }^{206}$ Due to the influence of a largely conservative rural vote, a moderate elite influence persisted in state politics despite the earlier demise of the Federalists as a party at that level and the stirrings of democratic politics in the cities. ${ }^{207}$ Thus, the courts emerged as the venue of choice for elites, seeking

203 Eliot 1837.

204 Vogel 2001.

205 Dahl 2005; Pole 1962; Vogel 2007a.

206 Dimond 1975; Warren 1931.

207 This more conservative cast of state politics persists in the Commonwealth of Massachusetts to this day. During the 1990s, wealthy investors ended a decades-long program of 'rent control', which limited the 
to reconsolidate both order and their own power, despite having by now lost control of elected office through an extended franchise and declining deference. ${ }^{208}$

What began as a subversive use of legality with respect to the British in the 1770s, however, now emerged, paradoxically, as a counter-revolutionary instrumentdampening what initial harvest of the Revolution there had been locally as manifested in, first, republican rule and, then, the nascent democratic impulse in America. ${ }^{209}$ In Massachusetts the task of consolidating America's postcolonial local governance had fallen, ironically, to the Whigs - the party of new business elites as well as old money. As the project unfolded, the effort to consolidate the freedom won from the British into a new local order reproduced constraints, albeit in altered form, that were often not too different from those that the Revolution had contested in terms of the prerogatives unaccountably accorded power.

In their effort to create a new vision of authority rooted in the 'rule of law', leaders grappled mightily, as did those in England after the first Reform Act of 1832, with the problem of cognoscibility of the law. ${ }^{210}$ My prior work suggests that they built on legal practices, both existing ones and some currently being set in place, to craft a more readily knowable type of law. ${ }^{211}$ I argue that it was in this setting that important changes in criminal law were introduced. Primary among these innovations to foster cognoscibility were the practices of drawing conflicts into the courts and of negotiating outcomes in criminal cases. That negotiation continues on a widespread and ongoing basis today as the practice we now call plea bargaining. ${ }^{212}$ Thus, we see the emergence in the shadow of the formal juridico-political power of the state of a largely private informal regulatory regime. It is one whose logic unfolds between adjudication and normalisation through 'negotiation', or 'self-regulation', to a customarily stipulated menu of penal norms regarding penalties. Not only did the practice provide a knowable customary legal process, it sported the capacious judicial discretion that has historically provided a window for the politicisation of law. ${ }^{213}$

amounts of increases that could be imposed on tenants, by passing legislation at the state level banning municipalities from operating such programs.

208 Vogel 2007a; Pole 1962.

209 'Counter-revolutionary' is used here to refer to efforts to impede the structural transformation that represents the fullness of a social revolution (Skocpol 1979).

210 Wiener 1993; Eliot 1837.

211 Vogel 1999 and 2001.

212 Vogel 2007a.

213 Neumann 1964. 


\section{THE MAKING OF POLITICAL AUTHORITY: THE PRIMARY ROLE OF LEGALITY}

In considering postcolonial political authority, it is useful to distinguish it from power. Power, according to Max Weber, is the ability to impose one's will, even over the opposition of another. ${ }^{214}$ Others offer different views including that of power as knowledge and discursive currency. ${ }^{215}$ Authority, in contrast, is 'the probability that a command ... will be [accepted and voluntarily] obeyed'. ${ }^{216}$ This is because authority entails both the sense of a right to command and a duty to comply. Authority is distinguished by its perceived legitimacy and, thus, its valid claim to subjective acceptance. ${ }^{217}$ Under authority, a sense of duty to obey is likely to avert the need for force or coercion. Max Weber has suggested that authority varies in type according to the basis of its legitimation. That basis may lie in tradition, charisma, or legality. ${ }^{218}$

In the years when the justificatory framework for governance in the American Republic was being laid, political leaders sought to articulate a vision of why commands and laws of the state must be obeyed even when counter to one's interests. The formal basis of compliance, as they saw it, was the rootedness of American government in law. ${ }^{219}$ Informed by the French experience of the 1790s, however, they began gradually, through a host of social practices, to bolster this vision of authority by reconnecting it with customary social hierarchies and the discursive power they retained. ${ }^{220}$ Their thinking in pursuing this 'embeddedness' was to provide guidance and support to the ordinary man for living according to law. ${ }^{221}$ These hierarchies were, as they saw it, honeycombed networks of social roles that reinforced the habits of ordered and harmonious living through the socialisation of the incumbents. Already we have seen that 'rule of law' discourse was a prevailing one and a crucial symbolic resource on which leaders drew. Let us explore now how they did so. In so doing, we consider both formal legal procedure and the cultural practices of discretionary informality that were increasingly becoming an integral part of legal practice.

\footnotetext{
214 Weber 1978, p 53.

215 Foucault 1979 and 1980; Lukes 2004; Kanter 1993; Marx 1992; Bachrach and Baratz 1970.

216 Weber 1978, p 53.

217 Ibid, 213.

$218 \mathrm{Ibid}, 215$. With traditional authority, legitimacy rests in a belief in the sacredness of the customs or traditions that underpin an order. Where authority is charismatic, legitimacy lies in the heroic strength or exemplary qualities of a leader. Under rational-legal authority, legitimacy has its basis in the 'legality of enacted rules and the right of those elevated to authority under such rules to issue commands' (ibid).

219 Tomlins 1993.

220 Vogel 2007a.

221 Vogel 2007b.
} 


\section{CRIME AND RIOTING: FEARS OF UNREST AMIDST LIMITED LOCAL GOVERNANCE}

Crime, rioting and unrest during the 1820s and 1830s focused political leaders on constructing a workable justificatory framework for local self-governance in an ever more urban, mobile and diverse society. The Reign of Terror in France had emblazoned the potential for democratic excess on the minds of thinking persons. It had led to the devastation of Napoleon's wars and then by the Bourbon Restoration. Revolution had been followed by violent excess and then, in short order, reversion to the monarchy, the resistance of the communes at mid-century and the imperial ascendancy of Louis Bonaparte shortly after. Doubts were rife in America as to whether self-rule would prove viable as an approach to governance. The question foremost in many minds was how to justify state actions and how to motivate compliance.

At this point, local government was institutionally very spare. Cities such as Boston were led by a mayor and town aldermen who were assisted by just a few constables, tax collectors and the courts. As Skowronek has pointed out, courts and tax collectors were in the 1830 s the main institutional presence of the state locally. ${ }^{222}$ It is not completely surprising that in America the courts emerged, as in England, as key institutions in the project of local governance. ${ }^{223}$ In England, the Quarter Sessions Courts simply assumed new tasks. ${ }^{224}$ The same tendency is evident in America. ${ }^{225}$ Since the basis of their broadened powers was not statutory and procedural rules did not strictly apply, the courts were free to handle many of these new tasks through discretionary means. The courts were involved not only in the practical aspects of governance but also, through their decisions and practices, in broader ones as well in crafting a conception of citizenship. ${ }^{226}$ I now examine how the practices and discretion of the courts, especially the criminal courts, contributed to the project of shaping both postcolonial local governance and a justificatory backdrop of political authority.

\footnotetext{
222 Skowronek 1982.

223 In England, during these same years, the Quarter Sessions were taking on with no new statutory authority a host of new tasks having to do with charters, licenses and the granting of rights of way.

224 Records of the Quarter Session courts in England show that the judges simply acted, without any formal mandate, to regulate and exert broader decision-making power in a host of new domains, especially those having to do with local governance such as charters for wharfs, regulation of prices and licensing (Quarter Session Courts (online), 'Introduction', National Archives, Kew, UK).

225 Vogel 2007a; Skowronek 1982.

226 Vogel 2007b.
} 


\section{THE COURTS AND RESPONSE TO DISORDER: RETHINKING LIBERTY}

In responding to disorder, the courts appear to have moved, first, to build on a series of decisions in labour law and political economy that emerged incrementally over several centuries to constrain the interpretation of freedom as one of 'embedded liberty'. ${ }^{27}$ Second, one finds a gradual shift in the procedural and institutional infrastructure toward one characterised by capacious discretion in responding to disputes arising out of the exercise of that freedom. In labour law, the courts produced a sequence of decisions regarding the 'free' worker's right to quit employment before the conclusion of an annual labour contract and steps an employer might take to persuade them to stay. ${ }^{228}$ In political economy, courts and local government deliberated on the nature and extent of regulation, rate setting, licensing and charters that restricted both access and the terms of trade in markets increasingly depicted as 'free'. ${ }^{229}$ In the criminal law, procedural innovations began to create opportunities for those charged to respond to a complaint against them through negotiation, yet court acceptance of such outcomes remained contingent on character testimony from local notables.

We find the law, then, in each of these areas grappling with new questions and engaging the individual as formally 'free' but — and this is an important but — at the same time legitimately structurally constrained. In each of these three areas of law, judges offered choices and rendered decisions on the basis that litigants were formally free. ${ }^{230}$ Yet, the courts moved at the same time to interpret that 'freedom' as appropriately limited by social structure and traditional hierarchies of power. ${ }^{231}$ The courts invoked, then, more or less contemporaneously across all three areas of law interpretations of liberty that were 'free' procedurally in a formal sense in terms of the ability to make voluntary choices but that were, in practice, very clearly structurally ringfenced in terms of the realities of what options a person could viably consider. This had enormous significance for citizenship in that it was coming to be conceptualised in America as defined in terms of a shared ideological commitment to liberty. ${ }^{232}$ For our purposes here, this notion of explicitly acknowledged structural constraint on liberty assumed added importance because it carried over into an emerging vision of political authority as well. What we find, as a result, is an approach to authority that combines both modern rational-legal and traditional elements.

227 Ibid.

228 Steinfeld 1991.

229 Sellers 1991.

230 Vogel 2007b.

231 Steinfeld 1991; Vogel 2007b.

232 Anbinder 1992; Sellers 1991. 


\section{PROCEDURAL FREEDOM IN THE CRIMINAL COURTS}

In the criminal law, judges turned to the ideology of the 'rule of law' to justify the courts' response to disorder. ${ }^{233}$ In this way, political officials sought to sidestep any appearance of either particularism or coercion unsuited to the government of a republic. ${ }^{234}$ At the same time, and equally important, judges began to exercise greater discretion in disposing of cases. ${ }^{235}$ These years also saw a shift both in England and America toward greater emphasis on the resolution of disputes arising from an alleged criminal act through the courts. ${ }^{236}$ This supplanted prior practice, originating in England, of cultural pressure for private settlement of alleged wrongs between the parties without recourse to the courts, sometimes through the payment of 'satisfaction'. 237

At the dawn of the nineteenth century, one also finds in America approval of a more active role for defendants in criminal cases. Most notable was a change in the decades immediately after the Revolution which allowed defendants to offer sworn testimony as witnesses in their own defence. This was a startling innovation, which is little remarked on in American legal history, but it contrasts starkly with Britain, where such testimony was not allowed until 1898. ${ }^{238}$ Such a limitation in England was defended on the grounds that, by wrongly protesting one's innocence in sworn testimony even for a minor crime, a defendant would perjure himself, which was a felony. Some suggested that this would amount to a sort of double jeopardy. It was also challenged as undermining the right to a free trial since negative inferences could be drawn from a failure to testify. Thus, we find in early to mid-nineteenth century America political efforts to encourage use of the courts for conflict resolution and initiatives to actively engage criminal litigants to do so. ${ }^{239}$ This is a significant and conscious shift in Anglo-American law. I have argued that it signalled a desire on the part of officials to forge a stronger relationship locally between the state and the populace. ${ }^{240}$ In a world whose inhabitants had only recently been set on an egalitarian footing politically and who, in an increasingly mobile society, were more often not personally known to each other, leaders determined that the state must play a larger

233 Following Dicey (1982), the rule of law entailed universality (or applicability to all), formal procedural equality in the treatment of all defendants and avoidance of ex post facto law.

234 EP Thompson (1975) has noted that, even where law serves the interests of the propertied, it cannot be used in ways that are blatantly unfair in the short term lest it be perceived as unjust and lose its claim on the behaviour of the populace.

235 Vogel 1999.

236 Hindus 1980. In England, records from the Quarter Sessions show more extensive involvement of the courts in criminal cases (Quarter Session Courts (online), 'Introduction', National Archives, Kew, UK). The same appears true in America (Hindus 1980).

237 Handlin and Handlin 1969; Quarter Session Courts (online) 'Introduction', National Archives, Kew, UK.

238 Baker 1979.

239 Vogel 1999; Hindus 1980.

240 Vogel 2007a. 
role locally in conflict resolution to uphold social order and, with it, political stability. This contrasts with the more remote and austere stance of the political subject before the centralised administrative state in Europe. ${ }^{241}$ The relationship that was cultivated appears to have been one of state moderation coupled with attempts by officials to achieve customary cognoscibility of the law by ordinary people.

Even as judges moved in America to exert dominion over crime and proposed a more active role for the accused, the nature of the relationship between the courts and litigants also changed. Subtly and gradually, the latitude afforded to judges to exercise their discretion expanded. ${ }^{242}$ As Neumann has so powerfully suggested, the expansion of latitude for discretion in court activity tends to open the way for politicisation of the law. 243

In many areas of law, judicial decisions began to be made with an eye not just to the prior cases and the principles established but also to their consequences for market activity and economic growth. ${ }^{244}$ Discretionary practices that often, but not always, involved grants of leniency had long been part of the common law in the criminal courts. They included the nolle prosse, the plea of nolo contendere, benefit of the clergy, the pardon and the conditional pardon, among others. ${ }^{245}$ In the case of the nolle prosse, a complaint that remained unprosecuted was often set aside but left to be resumed if future allegations of wrongdoing surfaced. This left the accused in a fragile and contingent position with respect to the law. Strong habitual offender legislation meant that any new complaint would result in prosecution as an habitual offender.

From the 1830s, discretion began to expand in criminal cases in new ways. This extension of judges' latitude for discretion centred on the practice of negotiating guilty pleas or 'plea bargaining'. ${ }^{246}$ The practice entailed the entry of a plea of guilty in anticipation of leniency from a judge or, later, a prosecutor. This practice was simple in form and so could be undertaken without the advice of an attorney. It was thus also inexpensive and could be accomplished rapidly. It brought closure to a case, which precluded a defendant's exposure to any future litigation for the offence at hand. The customary nature of the practice also helped to establish a knowable menu of punishable wrongs and the approximate tariffs to be imposed for each. This contrasted with the formal criminal procedure of the Anglo-American common law, where such knowledge could be had only after a judge had rendered his decision in a case. Americans for this

\footnotetext{
241 Anderson 2006.

242 Horwitz 1977.

243 Neumann 1964. In this way, Neumann presents a vision that is diametrically opposed to that of Schmitt (2007), who suggests that discretion in law is vital to keep politics democratic in spirit and in touch with the sentiments of a people.

244 Horwitz 1977.

245 Vogel 1999.

246 Vogel 2007a.
} 
reason had increasingly protested that the formal common law proceedings in criminal cases were not only a colonial residue but also effectively a form of 'ex post facto' law. ${ }^{247}$

Plea negotiation also offered policymakers some advantages, in that its leniency conveyed to litigants and the public alike a message of modulation on the part of the state. Most importantly, the capacious discretion it afforded judges gave them considerable control over sentencing policy. It allowed them to shape the penalties meted out in ways that reflected their policy sensibility. Since the judges in this period in Massachusetts were almost exclusively Whig appointments, their sensibility was very much at one with that Party. ${ }^{248}$ It was under the Whigs during the 1830s that negotiation of criminal cases on a significant and lasting basis appears to have begun in Massachusetts.

When plea bargaining first appeared in the lower courts of Boston during the 1830s, criminal cases were brief affairs involving almost exclusively a defendant and the judge. ${ }^{249}$ The extent to which leniency was granted was determined by the discretion of the judge, often relying on the testimony of character witnesses. Since a key objective of the courts was to distinguish those who had simply made a misstep in an otherwise worthy life from habitual miscreants and ne'er do wells who were grist for the House of Correction, the expanded discretion of judges provided the basis for a powerful social sorting mechanism. ${ }^{250}$ In making decisions regarding leniency, the courts often relied on witnesses as to a defendant's character, who typically were drawn from among employers or other established figures in the community. ${ }^{251}$ Surviving case files of the Superior Court reveal some handwritten notes on heavy cream stationery attesting to meritorious character and depicting some defendants as good fathers, hardworking men, faithful husbands and god-fearing persons. What this discretionary practice did was to give traditional hierarchies in the community a say in who would be spared heavier punishment.

What we find in this exercise of discretion by the courts is a curious blend of the modern egalitarian discourse of the rule of law with an institutional practice whereby the courts reinvigorated the power of traditional social hierarchies. This blend has parallels to that alluded to above in labour law, where rhetoric of the 'free' nature of labour coupled with judicial acknowledgment that this liberty was constrained by the realities of the worker's situation, especially the employer's financial leverage over payment. The judges recognised an employer's legitimate power to do all he could to ensure that the labourer's freedom of choice to leave was not exercised—such as refusing to pay for an entire season or even a year of work.

Similarly, in political economy, even as the discourse of 'market revolution' and 'free markets' gathered momentum, the courts upheld practices such as issuing charters,

247 Horwitz 1977.

248 Vogel 2001.

249 Gil 1837.

250 Vogel 2007a.

251 Lacey 2008; Gil 1837. 
licensing, granting of rights of way, rate setting and approving permits for canal building that powerfully shaped the terms of economic competition, often in favour of established economic actors. In each area of law, action that was deemed by the courts to be formally procedurally free was recognised as also embedded in a powerful and sometimes determinate context of structural constraint. In this way, the equality of the modern rule of law became intertwined with and limited by the hierarchal power of traditional privilege. Let us see how the next step was taken to move from this stance of the courts on freedom to a postcolonial conception of political authority.

\section{BUILDING ON POST-REVOLUTIONARY EXPERIENCE IN FRANCE}

During the American Revolution, monarchical authority exercised by the British through colonial rule was repudiated. In its aftermath, the task of re-establishing political authority fell to the new republic's leaders. In setting themselves to this task, the prevailing discourse of the rule of law, despite its being a legacy of British rule, was drawn on. ${ }^{252}$ Thus, both the judiciary and the legal residues of the colonial experience were implicated from the start in the construction of authoritative post-Revolutionary governance.

With the chaotic violence of the French Reign of Terror much in mind, American leaders had concluded that a people who were turned out of their everyday social role structures, as in France, might overturn property arrangements or, even, turn to mob rule. In moving to reassert postcolonial authority, they determined that reliance on the stabilising web of community relationships was essential for order. Yet how could the modern imagery of a rule of law and integration through the obligations of social roles be combined to create a mindset such that rules and commands would evoke a sense of duty to obey, even when not in one's immediate interest to do so? With state coercion sidelined because it suggested a political failure to represent the popular will, an approach that elicited subjective acceptance was urgently needed. Gradually reliance was placed on political and legal mechanisms that tended to elicit voluntary compliance on the part of citizens. These were believed to be more consistent with the autonomy touted by republicanism and implied subjective consent.

As political leaders moved to confront these twin problems of maintaining social order and institutionalising authority, they turned to the courts. They did so because, as we have seen, there was little else in the way of local governing institutions yet in place. ${ }^{253}$ Thus local leaders moved during the 1830s to draw on the existing legal infrastructure and to expand the role of the courts in ways similar to what was happening in England in those years. As the gaze of officialdom turned to the courts, along with the imagery of a 
rule of law various sorts of settlement practices employing discretionary informality assumed particular importance. ${ }^{254}$ We know that as early as the 1790 s these practices helped defuse complaints about delays, incognoscibility of the law and costliness. ${ }^{255}$

What was most significant about these practices was the new broad discretion they granted to judges. In contrast with earlier practices such as the nolle prosse and, especially, the plea of nolo contendere, which, as we have seen, normally required the assistance of legal counsel, judges in the lower criminal courts in Boston began during the 1830s to grant leniency when a defendant pled guilty. ${ }^{256}$

So at a time when local officials in Boston voiced mounting concern about rising crime, riots and the viability of democracy, judges in the lower court, the Boston Police Court (renamed in 1866 the Boston Municipal Court), began using their discretion to deal with criminal cases on a widespread basis in a new way. Whereas previously those accused were warned to exercise the hard-won legal protections of the republic by protesting their innocence, judges now began during the 1830s to accept growing numbers of guilty pleas. Here one sees that guilty pleas rise from the mid-1830s to the 1880s when they decline slightly and then plateau off. As guilty pleas rose in frequency over the next few decades, we asked whether those pleading guilty fared better, a sign that they had, in fact, received leniency from the courts. Statistical analysis has shown that those pleading guilty tended to fare better than those pleading not guilty primarily for crimes of property and crimes against the person. Morals offences tended, interestingly, to produce a more severe penalty when a guilty plea was entered until after the American Civil War had ended in 1865.

It is interesting politically to note that leniency was not automatically granted in these cases. In order to win leniency, it appears to have been necessary that a judge be persuaded

254 Handlin and Handlin 1969.

$255 \mathrm{Ibid}$. These problems were first highlighted when American soldiers returned from the Revolutionary War, having been at best partially paid for their services, to find themselves declared debtors and their homes seized by the state for unpaid taxes. This provoked an insurrection known as Shay's Rebellion.

256 Vogel 2007a. In a methodologically flawed study, one scholar, George Fisher (2004), has tried to argue that the practice appears briefly in the late 1700s. Fisher's study of the state Municipal Courts, later renamed the Superior Courts, in Essex north of Boston finds just a few dozen pleas of nolo contendere along with a few dozen guilty pleas in the higher court there over the 60 year period between the 1760 s and 1820s. Though he claims to be talking about guilty plea bargaining, Fisher combines these two groups of cases to attempt to claim that the appearance of just two or three cases per year of what he leads us to think all involve guilty pleas constitute an historical trend. Less than a handful of cases would not, of course, be sufficient by most methodological standpoints to support such a claim. There is a further problem in that, when one looks closely at his numbers, it becomes clear that, despite claiming to talk about guilty plea bargaining, he is also lumping in the pleas of nolo contendere which have quite different implications. Further, Fisher then tells us that even this dribble of misrecognised cases (ie less than a handful per year) suddenly stops in Essex until the mid- to late 1840s when substantial numbers of guilty pleas first appear accompanied by what Fisher argues to be evidence of leniency. Thus, for Fisher, bargaining on the basis of guilty pleas actually first arises as a significant continuing phenomenon in the higher courts in the Commonwealth of Massachusetts during the 1840s - about a decade after my own study shows negotiated guilty pleas to arise prominently in the lower courts of Boston (Vogel 1999 and 2007a). 
of the basically good character and productive life of the accused. ${ }^{257}$ To obtain this information, the courts turned, as we have seen, to character witnesses drawn from among established community members. ${ }^{258}$ In a country already known by the 1830 s for its litigiousness, the demographic and social composition of such witnesses was a reminder of the residual power of traditional elites. ${ }^{259}$ For in America, in contrast to France, revolution had not brought thoroughgoing social transformation so that traditional hierarchies remained largely intact. ${ }^{260}$

As part of the movement by the courts to promote stability and social order, a final element that has not previously been mentioned was emphasised. This was the use of recognisance or suretyship — a set of practices for ensuring good behaviour, most often by posting a bond that would be forfeit if laws were subsequently breached. ${ }^{261}$ It had been borrowed earlier, along with the tradition of discretionary leniency, from the old English common law. In America, these practices came to be linked during the mid-1830s to the new way of negotiating the outcomes of criminal cases. ${ }^{262}$ This new approach, which came to be referred to as the 'plea bargain', was used with increasing frequency in Massachusetts from the 1830s through the antebellum years. By the 1840s, it was being used widely in New York as well. ${ }^{263}$ While it had been customary in earlier discretionary common law practices, previously discussed, for favourable testimony by character witnesses to play a part in the granting of leniency, the widespread use of negotiated guilty pleas seems to have extended this so that these intercessors became persons under whose watchful eye a defendant might also be turned back into the community. ${ }^{264}$ Consequently, defendants with community ties were distinguished from others. Servants and women or minors, who lived under the authority of a head of household, as well as labourers, who were under contract and supervised by a master, were favoured over peddlers, vagrants and others who were living free from household governance. The result was to further reconnect the functioning of law with the traditional hierarchies of informal authority in a way that reinforced existing role structures in contrast to their earlier devastation in France. By doing so, I suggest, judicial exercise of discretion increasingly linked the rule of law-based rational-legal authority of the courts with the traditional authority of informal social hierarchies that had historically been a cornerstone of communal governance. Among the time-honoured hierarchies most frequently drawn on were two:

\footnotetext{
257 Lacey 2008; Vogel 2007a.

258 Lacey 2008; Vogel 2007a.

259 Konig 1979.

260 Wood 1992.

261 Simon 1993. Suretyship was a practice whereby offenders were restored to the community as long as they honoured a promise to observe good behaviour. Sometimes a bond was posted that would be forfeit if the conditions of the release were breached.

262 Vogel 2007a.

263 McConville and Mirsky 2005.

264 Vogel 2007a.
} 
the patriarchal authority of heads of households over dependants and servants, and the authority of the master over a labourer in the workplace. ${ }^{265}$

Even as the discourse of the rule of law touted universality and formal procedural equality before the law and as it prohibited ex post facto law, practices of discretionary leniency, and in particular the negotiated guilty plea, conveyed a somewhat nuanced and different message. These practices highlighted the residual influence of elite power both through the choices of Whig-appointed judges and the character references from employers and local notables. While respecting the autonomy of the citizen, in a formal sense, to choose how to plead, judicial discretion relied on informal hierarchies, in fact, in determining whether leniency would be granted. ${ }^{266}$ Thus, the political subject found her- or himself standing before 'law' that was composed in equal parts of modernity and tradition.

This recognition of traditional hierarchy has clear parallels with but also differs from law's stance toward the postcolonial political subject. ${ }^{267}$ There, the reader may recall, we found the subject identified in terms of a shared commitment to freedom in an imagined community. Recall, too, that the nature of that freedom was what I have called 'embedded liberty'. It viewed the person as, at once, formally procedurally autonomous but also legitimately restricted by structural constraints, including the power of customary hierarchies. This concept of 'embedded liberty', then, recognised both modern and traditional elements. As shown elsewhere, this view of the person possessed of 'embedded liberty' emerged as the model for thinking about the postcolonial political subject. ${ }^{268}$ The Whig vision of the politically and economically 'embedded' person had the advantage, from the viewpoint of leaders, that such connected individuals could be expected to live in a world of hierarchy and inequality but, unlike the dispossessed or disaffiliated, remain relatively immune to their fellows' summons to collective action for change due to their vested interest in sustaining the extant order. ${ }^{269}$ In thinking about political authority, leaders appear next to have moved a step further to build on their sense of the nascent postcolonial political subject by bolstering the discursive authority of the 'rule of law'. This involved fostering a tempering and engaged participation in local society, civic life, work, family, churches and voluntary associations. ${ }^{270}$

265 Steinfeld 1991, p 66.

266 Vogel 2001.

267 Vogel 2007b.

$268 \mathrm{Ibid}$. It emphasised the autonomy of the person as master of his or her own fate but within acknowledged limits of constraining social relationships and, until the 1820s, accorded scant attention to the exercise of rights (Vogel 2007a, 2007b and Vogel forthcoming). Only with the rise to power of the Jacksonian Democrats during the 1820 s and 1830 s did a rights-based liberal discourse begin to emerge as a local source of discursive contestation and an expression of the Democratic programme.

269 This task of articulating a political identity amidst rapid social change appears, as we have seen elsewhere, central to the cultural movement of the Second Great Awakening of this period (McLoughlin 1980).

270 de Tocqueville 1837; Putnam 1994. 
How to inculcate this identity and draw on it to foster compliance with governance was a matter of great controversy. It prompted vociferous debates over education and other institutional means for accomplishing it. Public schools were introduced to 'teach patriotism [and] encourage participation in civic affairs' ${ }^{271}$ Courts were also emphasised as places to reform the wayward. ${ }^{272}$ However, the educative role of the courts went well beyond reform in that, through judicial decisions as well as the commentary of judges and criminal sentencing, they conveyed to the populace not only knowledge of society's rules and the penalties that could be expected for violation but also a basic grasp of the norms of the society towards which they might adapt their behaviour in order to prosper. ${ }^{273}$ In appointing judges, officials increasingly pointed to a capacity for moral instruction as a qualification.

But if a sense of responsibility was to be imbued and compliance won, leaders sensed that something more than socialisation was needed to mobilise popular commitment to the new nation and its laws. Faced with the lack of a 'natural' demos, political leaders had focused on an idea to which a shared public commitment could be nurtured as the basis of political identity. The idea was 'liberty'. It answered the question of what was the nature of the American political subject. She or he was a person committed to 'freedom'. ${ }^{274}$ What was at this point only a subtext, however, was that the type of liberty nurtured would be of the dualistic or 'embedded' sort. ${ }^{275}$ To answer the question of why that subject, now understood as 'free', would voluntarily obey laws even when contrary to their immediate interests, however, Americans turned to bolster the discourse of the 'rule of law' with the realpolitik of the customary sway of hierarchical governance. Thus, they began in their rationale for compliance with state commands to combine the symbolic imagery of modernity's commitment to rules enacted in law and officials lawfully chosen with customary respect for traditional elite power. In referring to the 'rule of law', it was law articulating a concept of 'embedded liberty' and then drawing on the structural constraints nodded to in that concept to bolster discursive power with both the institutional authority of hierarchies but also their techniques of surveillance, classification and sorting in the service of social control. What we find, then, as a result, is an approach to authority that combines both modern rational-legal and also traditional elements. Interestingly, they were elements that combined the rational-legal and traditional legitimation of authority with the discursive and classificatory power of social control. The result was a formidable pillar of governance.

271 Carlson 1975; Kaestle 1983, p 72.

272 Anbinder 1992.

273 Sellers 1991.

274 Anbinder 1992; Sellers 1991; Higham 1955.

275 Vogel 2007b. 


\section{BASIS IN REPUBLICANISM FOR THE COMMITMENT TO LIBERTY}

In addressing the problem of maintaining social order, the republic not only needed to respond to breaches of law. It also sought to establish secondary social control— that is, to articulate social norms and laws and to imbue the populace with an understanding of the duties and responsibilities that accrued to them. The earliest view of the postcolonial political subject in America was an essentially republican one. It envisioned participation in public affairs by civic-spirited persons who saw themselves as pursuing a 'common good' and as linked to those more or less privileged through relations of deference. ${ }^{276} \mathrm{In}$ this way, republicanism differed in modernity from democracy, which focused more heavily on individual rights. ${ }^{277}$ Traditional republicanism necessarily presumed a 'moral consensus' in order to allow for the possibility of discerning a common good. ${ }^{278}$ Thus, politics in the republic assumed a 'normative character'. ${ }^{279}$ Ability to know this common good required a sound political process that protected 'the independence of mind and judgment' that each citizen brings to the deliberative process. ${ }^{280}$ Thus, politics in the republic was irrevocably contingent on liberty. The emphasis placed on a shared commitment to liberty as a basis for thinking the political subject was far from accidental. It was born of the very nature of the republican, rather than democratic, form of polity in the immediate aftermath of the revolution in America. ${ }^{281}$

Inevitably the republican cast of postcolonial American politics heightened the importance of law. This is because it was the work of legality to assure the existence of those conditions of autonomy required for free public discourse to ascertain the 'common good' that republicans sought. ${ }^{282}$ This sense that self-rule was necessarily rooted in law persisted in Massachusetts into the mid-nineteenth century even after deference faded, popular democratic politics had mobilised and elite dominance of elected office was replaced by a multiplicity of parties and hybrid political initiatives. By that time, however, law's role had expanded from one of an enabling condition for civic-spirited republican decision making to the basis of legitimation for 'democratic' political authority. Eventually, republican discourse was superseded as the nineteenth century wore on in America

276 Michelman 1988, p 1503; Pocock 1975. Note that this moves beyond Marshall's classic definition of citizenship as a 'status' that 'endows equality' with respect to rights and duties; Soysal's 'endowment of rights'; and Somers' 'instituted process' that accords rights.

277 Habermas 1998.

278 In America, utilitarianism, which sets out to foster 'the greatest good of the greatest number', thus embodying an implicit normativity, appear to have slightly preceded forms of liberalism that prioritised the right over any particular conception of the good (Bentham 1789 and 1827; Beccaria 1995; Sandel 1998; Kant 1784; Emerson 1840).

279 Michelman 1988, pp 1503-4.

$280 \mathrm{Ibid}, 1504$.

281 Skinner 1997.

282 Michelman 1988, p 1505. 
by a liberal one. But it was earlier republican discourse of the 1820 s and 1830s that provided the context for envisioning postcolonial authority. One crucial challenge in thinking about authority was how to reconcile techniques of social ordering with political liberty as both republican and liberal political currents stirred.

\section{LEGAL DISCRETION AND THE IMPORTATION OF EARLIER HIERARCHICAL MODELS OF GOVERNANCE}

During the early nineteenth century, the discourse of Bostonians, like Americans generally, was still influenced by colonial ideas of a hierarchical social order, though this was slowly beginning to change. ${ }^{283}$ Legal use of discretion, especially the negotiated guilty plea, drawing as it did on testimony from established community figures regarding character, intertwined elements of old and new governance in a way consistent with the emerging dualistic view of freedom in terms of which the political subject was increasingly conceived. It 'embedded' defendants by highlighting not only their free choices but also their ties to patrons in the social hierarchies they inhabited. At the same time, it often placed defendants who received leniency back into those community hierarchies of family and work, among others, under the customary care of their intercessors. In the process of the lower courts' social sorting, it distinguished those with social ties to their community from those without them as a proxy for the character of which Nicola Lacey speaks. ${ }^{284}$

Amidst the elite-dominated politics of Brahmin Boston, notions of social hierarchy and deference had prevailed into the early nineteenth century. ${ }^{285}$ In part, this was because the mercantile, maritime and financial base of the city's economy valued the role of 'producers' and manufacturers less then elsewhere. However, even in Boston, republican ideas, market activity and rural-urban migration were starting to erode hierarchies and the tendency to rely on one's 'betters' at home and at work. By exploring these ideas of hierarchical governance, we gain further insight into the formation of postcolonial political authority, which was taking shape at this time, and the political subject on which it rested.

In the early nineteenth century, the question of social ordering was viewed, as in the past, as one of maintaining traditional social hierarchies. ${ }^{286}$ Colonial Americans, like the early modern English, had drawn on 'two basic sets of [ideas to envision] ... how [those] ... who depended on or labored for others fit into their collective lives' ${ }^{287}$ First, masters of households held jurisdiction over servants working under their roof as they did over

283 Pole 1962.

284 Lacey 2008.

285 Pole 1962; Dahl 2005; Warren 1931.

286 Vogel 2007b.

287 Steinfeld 1991, p 55. 
family members 'by virtue of their [own] status as heads of household'. ${ }^{288}$ This authority of the master applied to indentured servants, hired domestic servants and apprentices. Second, Masters in the workplace exercised authority more broadly by virtue of a 'grant of jurisdiction from the community'. ${ }^{289}$ Workers governed in this way were normally employed in non-domestic production and were generally wage labourers operating under contract.

In thinking of the authority that masters exercised over resident servants, Americans historically drew on 'a set of ancient conceptions about proper order in the domestic household and about the role of the household in the wider polity'. ${ }^{290}$ Essentially they viewed the household as a hierarchically arranged polity, an idea similar to that in many other cultures over the centuries. ${ }^{291}$ This image conceptualised the authority of masters as 'one form of the relationship [that] heads of household bore to [their] dependent members' ${ }^{292}$ It had important legal implications. According to this conception, '[o]ne unrelated person could become the legal dependent of another ... [and come under their governance] because of the nature of the [contractual] agreement between them'. ${ }^{293}$ Resident servants, then, were 'like wives and children' because, as household members, they were legally dependent on its head. As dependants, servants historically were 'legally entitled to be maintained by the head of household ... [and] were subject by law to his authority' such that 'responsibility for all of them [before the law] rested on the head of ... household'. 294 Thus, a master was historically involved in any legal proceeding involving the servant.

In this way, 'servants came under [both] the "government" of the head of household' and that of the state. ${ }^{295}$ This responsibility of the master of the household had some similarities to the juridico-welfarist burden that accrued to towns and villages through 'settlement'. Since parallels between domestic and political authority were common, it is not surprising that 'the household ... [came to be] understood to be a polity like other polities, and the head of the household ... like those [leaders] who governed other polities' ${ }^{296}$ In the words of William Gouge much earlier in 1622, the family was a kind of proving ground for leadership. ${ }^{297}$ In a very explicit sense, household governance was seen as one building block of political order.

288 Ibid.

289 Ibid.

290 Ibid, 56.

291 Ibid; Ladurie 1979; Stone 1979, pp 93-104, 109-13.

292 Steinfeld 1991, p 56.

293 Ibid.

294 Ibid.

295 Ibid.

296 Ibid, 57.

297 Gouge (1622) tells us that the family 'is a little Church, and a little commonwealth, at least a lively representation thereof, whereby triall may be made of such as are fit for any place of authorities, or of subjection 
In contrast to the responsibilities of masters for their resident servants, which had their basis in domestic authority, masters' source of authority over nonresidential wageworkers lay in 'community jurisdiction over the laboring poor' ${ }^{298}$ In early modern English society, this group was seen as 'a common resource to which the community had rights, and laborers and artificers had legal obligations to make that resource available to [the] community ... on terms and conditions the community prescribed' - an idea that persisted among elites for centuries in England. ${ }^{299}$ Mobility of labour was perceived as problematic because 'it threatened to disrupt [arrangements of production and thus] good order as English elites then defined it'. ${ }^{300}$ By the 1560s the Statute of Artificers had provided that 'workers could not legally interrupt or leave their work without first securing their master's approval'. ${ }^{301}$ Masters held jurisdiction, though it was a more limited and temporary one than with residential servants, over the movements of labourers and artificers for several centuries.

These insights into the legal status of labourers shed important light on the political status of workers. In contrast to domestic servants, labourers, while also hierarchically dependent, supported households of their own. In contrast to servants, they also had 'independent political persona; they were listed separately as members of the polity [though,] unlike members of the higher orders, ... laborers and artificers were described as men who are ruled'. ${ }^{302}$ This view of labour as men who are ruled was part of an explicitly hierarchical understanding of the English polity of the day. It was one imported to early colonial America. As depicted earlier in Sir Thomas Smith's De Republica Anglorum, the English polity of Elizabethan times had been a hierarchy constituted of four ranks. ${ }^{303}$ Persons of even the lowest rank, Smith tells us, had to be taken into account politically because when courts 'default of yeomen, enquests and Juries are impaneled of such manner of people'. ${ }^{304}$ Thus, the hierarchy was inclusive.

By the eighteenth century, however, the political status of labour had changed. Labourers increasingly "were ... described as "their own masters" - at least outside of

in Church or commonwealth ... it is as a schoole wherein the first principles and grounds of government and subjection are learned: whereby men are fitted to greater matters in Church or commonwealth' (cited in Steinfeld 1991, p 57).

298 Steinfeld 1991, p 60.

299 Ibid, 60-62.

300 Ibid, 63.

301 Ibid, 60 .

302 Kussmaul 1981, pp 3, 8-9; Chamberlayne 1669, p 449.

303 'In the highest rank stood the "Nobilitas Major"; just below them stood the "Nobilitas Minor". The third rank is said to have been composed of "Citizens, Burgesses and Yeomen". The lowest rank was composed of laborers and artificers, among others' (Smith 1583, pp 29-47; Steinfeld 1991, p 65). More specifically, the fourth rank included 'day labourers, poore husbandmen, yea merchants or retailers which have no free lande, copiholders, and all artificers, as Taylors, Shoomakers, Carpenters, Brickemakers, Bricklayers, Masons, \&c' (Smith 1583, p 46, cited in Steinfeld 1991, p 65).

304 Smith 1583, p 46. 
work' ${ }^{305}$ Yet, in England, 'the [restrictive] provisions of the Statute of Artificers ... remained in effect throughout the century' ${ }^{306}$ Further, they were bolstered by new acts that 'made it an imprisonable offense for artificers and laborers to breach their [labour] contracts'. ${ }^{307}$ Thus, labourers and artificers, by the dawn of the nineteenth century, occupied 'an ambiguous legal position—not [completely any longer] the legal dependants of a master but not yet quite fully free ... citizens either' ${ }^{308}$

\section{PARTIAL TRANSFORMATION OF LIBERTY IN A CONTINUING CONTEXT OF HIERARCHICAL GOVERNANCE}

The view of labour as property and living under the governance of others, as just described, was consonant with a society that was hierarchically organised even after cultural justifications of social rank began to be challenged by modern political ideologies in the late sixteenth century. Steinfeld points out that 'the social and political theory known as "possessive individualism", which emerged ... during the seventeenth century, proceeded ... from ... premises' fundamentally different from those underlying hierarchical ideas of the polity. ${ }^{309}$ While one might think that these premises, which became the basis for the 'rights of freeborn Englishmen', would have immediately challenged hierarchical, and sometimes patrimonial, views of labour and society, this was only partially so.

Possessive individualism stemmed from the idea that 'social order was constituted by numerous separate, autonomous [and] essentially uniform individuals' ${ }^{310}$ This natural sovereignty over one's own person was seen as 'an expression of the fact that all individuals, to begin with, own themselves'. ${ }^{311}$ MacPherson went on to argue that ' $[\mathrm{n}]$ ot only has the individual a property in his own person and capacities ... [but] it is this property [that gives a person her or his humanity] ... that is, her or his freedom from other men'. ${ }^{312}$ There followed historically a long debate over how the alienation of that

310 Ibid. John Locke, a primary proponent of this perspective, explained that 'every man is put under a necessity, by his constitution as an intelligent being, to be determined in willing by his own thought and judgment what is best for him to do; else would he not be under the determination of some other than himself, which is want of liberty' (cited in Steinfeld 1991, p 79).

311 MacPherson 1962.

312 Ibid, 142.
} 
property in one's person through a labour contract could be reconciled with one's basic humanity rooted in autonomy. ${ }^{313}$ While independent persons safeguarded that sovereignty, wageworkers were seen to have alienated their right to dispose of and control that property in their person and its capacities. ${ }^{314}$ Actually, however, 'that alienation [was] not an abandonment but a transfer of right to the master' ${ }^{315}$ Possessive individualism began to change the way that transfer was envisioned. With the rise of the discourse of possessive individualism ' $\mathrm{t}$ ] he property ... [of] masters ... in the labor of their servants now began to be reimagined as the product of a voluntary transaction struck between two ... autonomous individuals, one of whom traded away to the other the property in his own labor for ... compensation'. ${ }^{316}$ This conception of the labour agreement persisted relatively unchanged for much of the eighteenth century. ${ }^{317}$

During these centuries, the status of labour also changed in other ways. If possessive individualism initially left the status of the worker largely unchanged, the ideology of the 'freeborn Englishman' did not. ${ }^{318}$ In the seventeenth century, these rights had risen to prominence during the English Revolution. By that century's end, such rights had come to be recognised as a defining element of English culture. ${ }^{319}$ In legal terms, this implied that all Englishmen were liberi homines or free men. ${ }^{320}$ This implied an element of equality and a fundamental challenge to hierarchical authority. ${ }^{321}$ Nonetheless the restricted status of servants and labourers continued to endure into the nineteenth century. How was this possible?

By the seventeenth and, especially, the late eighteenth century, the notion of the 'rights of freeborn Englishmen' began to be used to challenge legal understandings of ordinary service. Steinfeld notes that, in American political culture too, ' [c] onsent ... was becoming basic to the legitimate exercise of authority ... [a]nd the voluntariness ... [of] ordinary service ... was ... [seen as] expressive of a consent to be governed by a master ... [to whom service was] therefore arguably legitimate ... [and the] opposite of ... [the situ-

313 Vogel 2007b.

314 Wage workers 'had sold off part of their paternity, the right to the exclusive use and possession of their capacities, to their masters in exchange for wages' (Steinfeld 1991, p 80).

315 Ibid.

316 Ibid.

317 Ibid, 81.

318 Thompson 1963.

319 Ibid.

320 Steinfeld 1991, p 95.

321 Lord Roger Coke observed that ' $\mathrm{t}$ ] wo parts of three have not forty shillings a year, yet are as free born as they who have' (1662, cited in Steinfeld 1991, p 96). Leveller Richard Overton drew on this 'shared status of all Englishmen' to mean that 'the greatest Peers in the land' should not be more respected 'than so many old bellows-menders, broom-men, cobblers, tinkers or chimney-sweepers, who are all equally free born' (cited in Steinfeld 1991, p 96). At the same time, Levellers began to 'equate "all infringements of their liberties” with slavery' (Thomas 1974, p 75). By 1669, Chamberlayne tells us that 'Foreign Slaves in England are none ... A Foreign Slave brought into England, is upon landing ipso facto free from Slavery, but not from ordinary service' (Chamberlayne 1669, p 462). 
ation of] slaves and villeins'. ${ }^{322}$ The English still continued to observe the older distinction that property in labour performed was conveyed temporarily, in contrast to slavery, and, increasingly, that it 'was only one aspect of the property one held in one's person'. ${ }^{323}$ These distinctions prevailed in England through the eighteenth century. Ordinary service was depicted as 'consensual and limited' as well as partial, in contrast to slavery. ${ }^{324}$ One crucial assumption that made this distinction possible was the idea prevalent in England that 'freedom (and unfreedom) were not absolute[s] ... but [seemingly] matters of degree'. 325

\section{'EMBEDDED LIBERTY': THE CONSTRAINED AUTONOMY OF THE REPUBLICAN POLITICAL SUBJECT}

The appearance in the seventeenth and, especially, the late eighteenth centuries in England of liberal ideas introduced a new conception of freedom that at first seems very different. It challenged the idea that liberty could be a matter of degree. ${ }^{326}$ Now it was increasingly argued that 'he who has authority "to restrain and control my conduct in any instance without my consent hath in all"'.327 The concept of freedom as a matter of degree began to lose ground. Steinfeld notes that ' $[\mathrm{b}] \mathrm{y}$ the 18th century, all [absolute] legal restriction on a laborer's right to depart from his work [under any condition] seems to have been eliminated in the colonies' ${ }^{328}$ This autonomy and freedom to leave applied to labourers, but the status of hired servants continued to be more restricted.

The concept of the rights of the freeborn Englishman, on the one hand, and ideologies of republicanism and liberalism, on the other, also began to be used in England to contest the notion of labourers, under contract, as unfree. Traditional visions of society and polity as hierarchies based on rank, however, continued to prevail. ${ }^{329}$ Steinfeld notes that ' $\mathrm{t}$ ] he new philosophies did not ... [eliminate] traditional ... [images of labour]... [Instead], traditional practices often found [renewed] support, for novel reasons, in the new views'. ${ }^{330}$ In this light, it is not surprising that such early contractarian individualism did not lead directly to liberalism because it would have required that 'all people, whatever their circumstances, formally retain [at all times] the wall of rights separating and insulating them from other individuals' ${ }^{331}$

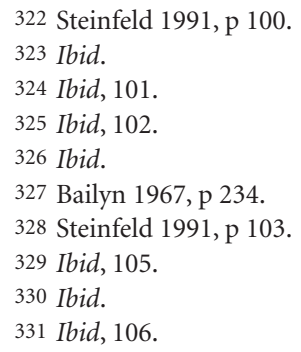


The answer to this growing tension in law was found by reconceptualising the nature of labour contracts. ${ }^{332}$ The dilemma was that all men were free but that, in exercising their freedom to make labour contracts, 'they ... [conveyed] a property in their capacities that enabled others to control them'. ${ }^{333}$ As long as traditional views of society as an authoritative hierarchy supported such arrangements, the tensions this created were masked. ${ }^{334}$ With the gradual weakening of hierarchy, particularly in America, during the early nineteenth century, the conflict began to surface fully. It was during these years that the Whig project of re-establishing authoritative postcolonial local rule was set in motion. The Whigs, responding to the stirrings of, first, republican and, then, democratic politics moved to reconsolidate their power by slowing change and reasserting the influence of hierarchy.

In 1821, the legal basis for landmark change on the question of the extent to which labourers were free was established in America in Mary Clark's Case, which articulated a new understanding of the freedom of labourers. ${ }^{335}$ Judges determined that 'labor became involuntary [and thus unfree and illegal] the moment a laborer decided to depart and was not permitted to do so-whatever previous agreements she may have made'. ${ }^{336}$ This case established the principle that, despite entering into the service of another, labourers and servants continued to reserve to themselves autonomy in their own lives. This accorded to labourers full juridical equality because they could not transfer irrevocably, even temporarily, control and disposition of their capacities. What was significant about this decision was that it 'left ultimate decision[s] formally to the laborer' ${ }^{337}$ By depicting the worker as formally free, a view of the labour relation consolidated that was quite compatible with the American spirit of 'republican liberty and equality'. ${ }^{338}$

As Steinfeld notes, what this left to masters was 'persuasion'. ${ }^{339}$ In this new view of labour law, masters no longer could claim a capacity to compel workers. Instead, they were restricted to 'influencing' workers' decisions made freely for themselves and to shaping the incentives faced by workers as they made their choices. ${ }^{340}$ Though employers could no longer coerce workers physically, they retained rights 'under property, contract and labor law ... [that] constituted the basis for economic power through which to [powerfully] ... influence wage workers' ${ }^{341}$ In the capacity that it gave to employers to persuade a worker to stay, the Clark decision, even as it defended the formal freedom of

332 Ibid.

333 Ibid, 107.

334 Ibid.

335 The Case of Mary Clark, a Woman of Color 1 Blackf 122, 124-25 (Ind 1821). Mary Clark's case involved an attempt by slaveholders to introduce slavery into free states by means of the vehicle of indentured servitude.

336 Steinfeld 1991, p 147.

337 Ibid, 148.

338 Ibid, 149.

339 Ibid, 148.

340 Ibid.

341 Ibid. 
the worker, reaffirmed the power of hierarchy. As had often been the case in colonial Massachusetts, litigation was once again used 'to define social rules' and the state of play in postcolonial America. ${ }^{342}$ Thus, coercion was, at least formally, barred and the focus of employment centred now on participatory consent. Yet, the structural influence of hierarchy remained a crucial part of the picture of power.

In formal terms at least, working persons would now retain mastery of themselves. ${ }^{343}$ The power of hierarchy would, however, not yet be fully denied. While ' $[\mathrm{d}]$ irect coercion ... [was] not ... permitted, ... legally sanctioned economic compulsion would [be]'. ${ }^{344}$ Masters were permitted 'to manipulate [unrestrainedly] the considerations that workers would weigh in arriving at their own decisions' to leave a labour contract. ${ }^{345}$ This included the capacity to withhold payment for months of labour already performed. ${ }^{346}$ Such, then, was the formal autonomy and 'freedom' accorded to the worker. Persons were now deemed formally free to choose, but society's institutions were afforded the latitude to structure the contours of the choice, the terms of 'trade', and the incentives embodied in them-at times to an extent that could render some options, for all practical purposes, non-viable.

While the law of employment relations explicitly theorised the labourer as political subject, the courts of criminal jurisdiction were rarely so explicit on that point. They focused instead on concepts of the 'reasonable man' and criminal intent instead. Yet one finds striking parallels with labour law, as shown in a previous paper, ${ }^{347}$ in the conception of liberty and image of the legal subject tacitly employed in the criminal courts. The accused, before the court, is portrayed as a 'reasonable man' and free to exercise that rationality in voluntary choices to which criminal responsibility accrues. As the nineteenth century advances, the defendant finds her- or himself free to choose a plea. At the same time, whether choosing a course of criminal action or deciding how to plead, she or he occupies a situation that is structurally constrained-by life circumstances as to options, on the one hand, or the power of the state as to terms of agreement, on the other. In neither case is the structural constraint interpreted as a restriction of 'freedom'. Labour law and criminal law differ, however, in that while decisions about the nature of 'free' labour help shape the formal legal standards of the day, ideas of 'freedom' and 'reasonableness' in the criminal courts are apparent both in doctrine and in informal and customary processes that arise at the interstices of formal practice.

First, as in labour law, criminal actions emphasise the autonomous choice and participation of formally free individuals in shaping their fates. In the case of the labourer, he or she is free to stay or go. For the criminal defendant, he or she is free to plead guilty

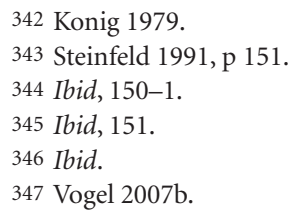


or not regardless of whether a bargain is being consummated. Second, both labourer and defendant, in the case of the plea bargain, enter a compact or covenant. In the case of the labourer, it is an agreement to serve for a specified amount of time at a given wage. The defendant in a criminal case may acknowledge culpability in the hope of eliciting leniency in return. Thus, both entail a two-sided agreement (ie labourer/master, defendant/judge or prosecutor) entered into by each to serve her or his respective interests. In both cases, however, the quality of the agreement that one can achieve is constrained by the prevailing terms of trade. Third, while the choice is formally free, those terms of trade may be powerfully leveraged by the more resource-rich participant. In the case of the labourer, this is typically the master. For the criminal defendant, it is the state. The agreements differ, of course, in that while the labour contract conforms to the formal legal standards of the day, the plea bargain is an informal and customary arrangement that arises in the interstices of formal practice. Public opinion of such a self-interested and ambitious practice is implied by the term 'bargain'. ${ }^{348}$

\section{POLITICAL AUTHORITY IN THE 'IMAGINED REPUBLIC'}

In shaping a regime of postcolonial power and authority, American leaders faced the challenge that the new state was being formed absent a demos and before a sense of nationality had been consolidated. Thus, the traditional forces of integration and cohesion that bind a people together and cause the society to cohere were absent. In this setting, a commitment and discourse gradually arose around 'liberty' as a common basis of political

348 Baxter 1995; Watson 1998; Vogel 2007a. While the practice of plea bargaining originated with the Whigs, the term 'bargain' appears to have been a colloquial one that came from the Democrats and to have been a pejorative reference to Henry Clay's 'corrupt bargain' which was again relevant in the electoral politics of the day (Vogel 2007a). It signified a suspension of principle in the service of ambition - the ambition of the Whig Party, whose legal improvisation produced the 'plea bargain' (Vogel 1999 and 2007a). The name communicated their disdain for the new process of pre-dispositional compromise. The lower criminal courts were under the oversight of the Governor of the Commonwealth of Massachusetts and, thus, were controlled by the Whigs who were seeking to reconsolidate elite political dominance in Boston and the Commonwealth of Massachusetts after the collapse of the Federalist Party. More specifically, the term appears to constitute a thinly veiled innuendo with its reference to Henry Clay's well-known 'corrupt bargain' with then-Presidential candidate John Quincy Adams of Massachusetts. In years when personal ambition for the Presidency was thought to be corrupt, Henry Clay had met with Whig John Quincy Adams in January 1825 and promised his support for the New Englander's quest for the Presidency (Watson 1990, p 81). When Adams was subsequently elected and Clay was named Secretary of State, Clay was alleged to have consummated a 'corrupt bargain' with the President-elect. Jacksonian Democrats then appear to have retaliated by associating the new discretionary practice of the Brahmin-run courts with the opportunistic tendencies of the Whigs, implying that it must have been this that led them to accord consideration to defendants in response to symbolic trucking and bartering in the courts. The term was almost certainly intended to portray the ambition, corruption and commercially oriented gain of the Whig ascendancy as antithetical to a true democratic spirit. 
identity. What sort of political subject, it was then wondered, could thus be formed? How could she or he be expected to participate responsibly in the project of self-rule and to obey the law even when not in her or his immediate interest to do so? This has come to be understood as a classic dilemma of sovereignty in a republic or democracy. ${ }^{349}$ How could the new order be inscribed in such a subject of power?

The relation between authority and identity is a complex and subtle one. As Dean suggests:

To understand the relation between authority and identity, ... we should look beyond ... state formation ... to the variegated domain in which what might be called 'regimes of government' come to work through 'regimes of conduct', a domain populated by the multiform projects, programmes and plans that attempt to make a difference to the way in which we live ... ${ }^{350}$

These 'authorities of truth', Dean tells us, work both within and outside state borders. They may press for expansion or diminution of function, reconfiguration or linkage with new networks. Alternately, they may circumvent or even bypass the state.

From the standpoint of the human subject of power, 'a multiplicity of authorities, movements and agencies come into play, seeking to link up our freedom, choices, forms of life and conduct with an often uncertain mix of political goals, social aspirations and governmental ends' ${ }^{351}$ In Minson's felicitous turn of phrase, Foucault focuses us on ways in which 'the conduct of government is linked to the government of conduct'. ${ }^{352}$ Dean reminds us that Foucault asked 'how we have come to problematize both our politics and our being in such a way that identity, subjectivity and self come to be hooked to questions of politics, authority and government'. ${ }^{353}$ Historians of antiquity have shown how styles of 'ethical comportment' and personality have been implicated in social hierarchies as well as in struggles for power throughout time. For instance, male notables of the Eastern Empire in the fourth century were groomed into a culture of paideia that inculcated certain attributes they must always show to those of lower rank. These included, especially, demonstrations of a desire to display continuing goodwill to one's city through civic beneficence such as restoration of buildings and the hosting of festivals and games, sometimes at great financial cost. ${ }^{354}$ In contrast, early Christian communities sought to cultivate 'simplicity, transparency to God and openness to others'. ${ }^{355}$ These projects of fostering a certain comportment were far from neutral or disinterested. Instead, they were often central to struggles over who might exercise leadership and how best to govern.

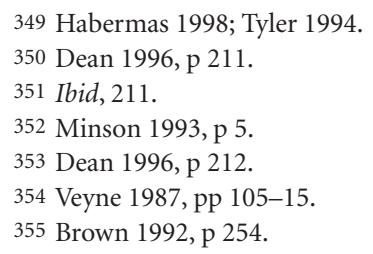


It is such preoccupations that are the focus of Foucault's concept of 'governmentality'. Governmentality concerns itself with 'more or less explicit attempts to problematise our lives, our forms of conduct and ourselves'. ${ }^{356}$ Scholars writing in this style focus on catechisms, books of etiquette, dietary regimens, 'how-to' books and works of popular psychological analysis. Dean sums up the project of governmentality thus:

If we are to talk of processes of socialization as a general way in which 'society' affects 'individuals', then we must give an account of how this socialization is itself constructed, the historical forms it takes, the rationalities it deploys, the techniques, mechanisms, practices and institutions by which and in which it is proposed that we work on, divide, make whole, sculpt, cultivate, pacify, contain, empower, and optimize not only our own lives, selves and conduct but the lives, selves and conduct of those over whom we claim some authority. ${ }^{357}$

Thus, the perspective of 'governmentality' enables us to problematise the political subject and the processes of its formation.

In postcolonial America, there was a recognition that an authoritative regime and discourse of local rule had to be reinvented anew-due both to the Revolutionary rupture from British colonial rule and to the lack of existing models for a viable postcolonial justificatory framework for day-to-day local governance. Awareness was strong that coercive power alone would not suffice, for, when a democratic government must use force to rule, it signals resistance and undermines the regime's claim to reflect the will of the people. In this setting, recourse was had to the prevailing discourse of a 'rule of law' as a rationale for compliance. Obey, said leaders, because we are your lawfully chosen officials and because we are acting in accordance with the rules that, together, we have enacted in law. Thus, legality emerged as the justification for authority in the new republic.

Such reliance on law, however, had a paradoxical and ironic element. This was because the discursive and coercive power of law was now deployed by the American Whigs-a party of old and new money alike in that country — who sought, by stabilising the existing order with the inequalities embedded in it, to reconsolidate their own political power. Thus, the discursive legacy of British rule in the form of the common law, which had inspired colonial resistance to British breaches of what were perceived as inviolable rights, now emerged in the hands of the American Whigs as a force for maintaining the extant social order. In this way, law, which had played a subversive part against the British, now acquired counter-transformative, or counter-revolutionary, overtones instead.

It appears to have been through this reliance on the discourse of a 'rule of law' that the Whigs came to comprehend and then to gradually rely on law's 'embeddedness' in the social institutions of everyday life. This also took them on a path that joined the juridicopolitical power of the state with the 'disciplinary regimes' anchored in the hierarchies of 
household and community governance and the middle-level institutions of everyday life. That is, it took the project of republican rule to a new mode of practice-from discourse to discipline.

In problematising postcolonial political authority, we find diverse 'authorities' and movements entering into play to link choices, ethics of conduct and subjectivity with diverse political agendas, social desires and governmental policies. We see that liberal constitutionalists historically have made a contribution in highlighting rights and protection of property but have downplayed too much: the limitations of those rights, both as interpreted and as implemented, elaboration of the state role to regimes of governmentality, and statist intervention in the name of a public interest. Instrumentalists correctly point to a pervasive policy focus on economic growth but soft-pedal partially autonomous political, cultural and legal dynamics linking 'authorities of truth' with styles of 'ethical comportment' in ways that can lead us to miss important parts of the story. Theorists of a 'well-regulated society' rightly grasp the persistence of social hierarchy in the antebellum years, the priority accorded to social ordering and the role of the common law in establishing it. What this view to some extent glosses over, however, is the multiplicity of discourses, ways in which governmentality shapes conduct and subjectivity, and the struggle of competing parties to appropriate and recast the meaning of the 'rule of law'.

\section{References \& Bibliography}

Anbinder, Tyler, Nativism and Slavery: The Northern Know Nothings and the Politics of the 1850s (Oxford University Press, 1992)

Anderson, Benedict, Imagined Communities: Reflections on the Origins and Spread of Nationalism (Verso, 2006)

Atkinson, Brooks (ed), The Complete Essays and Other Writings of Ralph Waldo Emerson (New York, 1840)

Bachrach, Peter and Morton Baratz, Power and Poverty: Theory and Practice (Oxford University Press, 1970)

Bailyn, Bernard, The Ideological Origins of the American Revolution (Harvard University Press, 1967)

Baker, JH, An Introduction to English Legal History (Butterworths, 1979)

Barron, Anne, 'Foucault and the Law' in Hugh Collins et al (eds), Introduction to Jurisprudence and Legal Theory (Oxford University Press, 2002)

Barry, Andrew, Thomas Usborne and Nikolas Rose, Foucault and Political Reason (University of Chicago Press, 1996)

Baxter, M, Henry Clay and the American System (University of Kentucky Press, 1995)

Beccaria, Cesare, Cesare Beccaria: On Crime and Punishments, R Bellamy (trans) (Cambridge University Press, 1995)

Bentham, Jeremy, The Rationale of Juridical Evidence (John Bowring, 1827)

Introduction to the Principles of Morals and Legislation (1789)

Bingham, Thomas, The Rule of Law (Penguin, 2011)

Bourdieu, Pierre, Outline of a Theory of Praxis (Harvard University Press, 1977)

Brown, P, Power and Persuasion in Late Antiquity (University of Wisconsin Press, 1992) 
Brubaker, Rogers, Citizenship and Nationhood in France and Germany (Harvard University Press, 1992)

Burke, Edmund, Reflections on the Revolution in France (1790)

Carlson, E, The Quest for Conformity: Americanization through Education (Wiley, 1975)

Chamberlayne, Edward, Angliae Notitia: Or, The Present State of England (London, 3rd edn 1669)

Corwin, Edward S, 'The "Higher Law" Background of American Constitutional Law' (1929) 42 Harvard Law Review 149-85, 365-409) 460-79

'The Doctrine of Due Process of Law before the Civil War' (1911) 24 Harvard Law Review 366-85,

Cremin, Lawrence, American Education: The National Experience (Harper and Row, 1980)

Dahl, Robert A, Who Governs? Democracy and Power in the American City (Yale University Press, 2005)

de Tocqueville, Alexis, Democracy in America, Gerald Bevan (trans) (Penguin, 2003 [1837])

Dean, Mitchell, 'Foucault, Government and the Enfolding of Authority' in Andrew Barry, Thomas Usborne and Nikolas Rose, Foucault and Political Reason (University of Chicago Press, 1996) 209-29

Dicey, AV, Introduction to the Study of the Law of the Constitution (Liberty Fund, 8th rev edn 1982)

Dimond, Alan J, A Short History of the Massachusetts Courts (National Center for State Courts, 1975)

Dobbin, Frank and T Dowd, 'The Market that Anti-Trust Built: Public Policy, Private Coercion and Railroad Acquisitions, 1825-1922' (2000) 65 American Sociological Review 631-57

Donzelot, Jacques, L'Invention du social (Fayard, 1984)

Dublin, Thomas, Women at Work (Columbia University Press, 1979)

Eliot, Samuel Atkins, Address to the Boston City Council, 18 September 1837, Archives of the Commonwealth of Massachusetts State House, Boston, MA

Emerson, Ralph Waldo, 'Self-Reliance' in Atkinson (1840)

Evans, Peter, Theda Skocpol and Dieter Rueschemeyer, Bringing the State Back In (Harvard University Press, 1985)

Ewald, François, L'Etat providence (Grasset, 1987)

Ferdinand, Theodore N, Boston's Lower Criminal Courts, 1840-1859 (University of Delaware Press, 1992)

Fischer, David Hackett, Albion's Seed: Four British Folkways in America (Oxford University Press, 1989)

Fisher, George, Plea Bargaining's Triumph (Stanford University Press, 2004)

Foucault, Michel, Madness and Civilization (Vintage, 1988a)

, Politics, Philosophy and Culture (Routledge, 1988b)

, History of Sexuality (Penguin, 1984)

, This is Not a Pipe (University of California Press, 1983)

, The Archaeology of Knowledge (Pantheon, 1982a)

, 'The Subject of Power' in Michel Foucault: Beyond Structuralism and Hermeneutics (University of Chicago Press, 1982b)

, 'Body/Power' in Colin Gordon (ed), Power/Knowledge (Pantheon, 1980)

Discipline and Punish (Vintage, 1979)

Friedman, Lawrence and Harry Scheiber, American Law and the Constitutional Order: Historical Perspectives (Harvard University Press, 1988)

Galligan, Denis, Discretionary Powers (Oxford University Press, 1990)

Giddens, Anthony, The Nation State and Violence (University of California Press, 1987)

Gil, Thomas, Court Vignettes from the Boston Morning Post (Widener Library Collection, Harvard University, 1837) 
Gordon, Robert W, 'Critical Legal Histories' (1984) 36 Stanford Law Review 57-125

Gouge, William, Of Domesticall Duties (London, 1622)

Gramsci, Antonio, Selections from the Cultural Writings (Harvard University Press, 1991)

, Selections from the Prison Notebooks (International Publishers, 1971)

Greene, Jack P and JR Pole, A Companion to the American Revolution (Blackwell, 2000)

Habermas, Jürgen, Between Facts and Norms (MIT Press, 1998)

Handlin, Oscar and Mary Handlin, Commonwealth: A Study of the Role of Government in the American Economy, Massachusetts, 1774-1862 (Belknap Press of Harvard University Press, 1969)

Hay, Douglas et al, Albion's Fatal Tree (Random House, 1975)

Hegel, GWF, The Philosophy of Right, TM Knox (trans) (Oxford University Press, 1967)

, The Philosophy of History (Dover, 1956)

Higham, John, Strangers in the Land (Greenwood, 1955)

Hindus, Michael, Prison and Plantation: Crime, Justice and Authority, 1767-1868 (University of North Carolina Press, 1980)

Hirschl, Ran, Towards Juristocracy: The Origins and Consequences of the New Constitutionalism (Harvard University Press, 2007)

Horwitz, Morton J, The Transformation of American Law, 1780-1860 (Harvard University Press, 1977)

Howe, Daniel W, The Political Culture of the American Whigs (University of Chicago Press, 1979)

Hurst, James W, The Growth of American Law (Lawbook Exchange, 2001)

Kaestle, Carl F, Pillars of the Republic: Common Schools and American Society, 1780-1860 (Hill and Wang, 1983)

Kairys, David (ed), The Politics of Law: A Progressive Critique (Pantheon, 1982)

Kant, Immanuel, What is Enlightenment? (Berlinische Monatsschrift, 1784)

Kanter, Rosabeth M, Men and Women of the Corporation (Basic Books, 1993)

Katznelson, Ira and Aristide Zolberg, Working Class Formation (Cambridge University Press, 1988)

Kelly, George A, 'Hegel's America' (1972) 2 Philosophy and Public Affairs 2-36

Kloppenberg, James T, 'Virtue' in Jack P Greene and JR Pole (eds), A Companion to the American Revolution (Blackwell, 2000) 696-700 'The Theory and Practice of American Legal History' (1993) 106 Harvard Law Review 1332-51

Knights, Peter R, Plain People of Boston, 1830-1860 (Oxford University Press, 1972)

Kohl, LF, The Politics of Individualism (Oxford University Press, 1991)

Konig, David T, Law and Authority in Puritan Massachusetts: Essex County, 1629-1692 (University of North Carolina Press, 1979)

Kussmaul, Ann, Servants in Husbandry in Early Modern England (Cambridge University Press, 1981)

Lacey, Nicola, 'Psychologising Jekyll, Demonising Hyde: The Strange Case of Criminal Responsibility' (2010) 4(2) Criminal Law and Philosophy 109-33.

Women, Crime and Character (Oxford University Press, 2008)

'In Search of the Responsible Legal Subject' (2001a) 64(3) Modern Law Review 350-71

'Responsibility and Modernity in Criminal Law' (2001b) 9 Journal of Political Philosophy 249-76.

Ladurie, Emmanuel, Montaillou (Vintage, 1979)

Lawrence, Abbott, Memoir of the Honorable Abbott Lawrence (JH Eastburn's Press, 1856)

Locke, John, Two Treatises of Government (Edes and Gill, 1773)

, An Essay Concerning Human Understanding (Thomas Baffet, 1690) 
Lounsbury, M and M Ventresca (eds), Social Structure and Organisation Revisited (JAI Press, 2002)

Lukes, Steven, Power (Palgrave Macmillan, 2nd rev edn 2004)

MacPherson, CB, The Political Theory of Possessive Individualism (Oxford University Press, 1962)

McConville, Mike and Chester L Mirsky, Jury Trials and Plea Bargaining (Hart Publishing, 2005)

McLoughlin, William, Revivals, Awakenings and Reform (University of Chicago Press, 1980)

Mann, Mary (ed), The Life and Works of Horace Mann (3 vols) (1867 (II))

Marshall, TH, Class, Citizenship, \& Social Development (University of Chicago Press, 1964)

Marx, Karl, Capital, vol I (Penguin, 1992)

Mensch, Elizabeth, 'The Colonial Origins of Liberal Property Rights' (1983) 31 Buffalo Law Review 635-735 , 'The History of Mainstream Legal Thought' in David Kairys (ed) The Politics of Law (Pantheon, 1982)

Michelman, Frank, 'Law’s Republic' (1988) 97(8) Yale Law Journal 1493-1597

Mill, JS, The Collected Works of John Stuart Mill, 'Principles of Political Economy', vols 2 and 3 (Liberty Fund, 2006) Press, 1975)

Minson, J, Questions of Conduct: Sexual Harassment, Citizenship and Government (Macmillan, 1993) 1985)

Genealogies of Morals: Nietzsche, Foucault and Donzelot and the Eccentricity of Ethics (Macmillan,

Monkkonen, Eric, Murder in New York City (University of California Press, 2001)

Montesquieu, Charles de, The Spirit of the Laws (Barrillot et Fils, 1750)

Montgomery, David, Workers' Control in America (Cambridge University Press, 1979)

Nelson, William, Dispute and Conflict Resolution in Plymouth Country, Massachusetts, 1725-1825 (University of North Carolina Press, 1981)

Neumann, Franz L, 'The Change in the Function of Law in Modern Society' in FL Neuman and H Marcuse, The Democratic and the Authoritarian State (Free Press, 1964)

Norton, Anne, Alternative Americas: A Reading of Antebellum Political Culture (Chicago University Press, 1986)

Novak, William J, The People's Welfare (University of North Carolina Press, 1996)

Orren, Karen, Belated Feudalism: Labor, the Law, and Liberal Development in the United States (Cambridge University Press, 1991)

Paine, Thomas, Common Sense (Philadelphia, 1776)

Parsons, Talcott, Politics and Social Structure (Free Press, 1969)

Pessen, E, Most Uncommon Jacksonians (SUNY Press, 1967)

Peterson, Merrill D, Thomas Jefferson: Writings (Library of America, 1984)

Piven, Frances and Richard Cloward, Poor People's Movements (Vintage, 1979)

Pizzorno, Alessandro, personal communication with the author, January 1986

Plant, Raymond, Modern Political Thought (Blackwell, 1991)

Pocock, JGA, The Machiavellian Moment: Florentine Political Thought and the Atlantic Republican Tradition (Princeton University Press, 1975)

Pole, JR, 'Equality' in Jack P Greene and JR Pole (eds), A Companion to the American Revolution (Blackwell, 2000) 
The Gift of Government: Political Responsibility from the English Restoration to American Independence (University of Georgia Press, 1983)

1979) Political Representation and the Origins of the American Republic (University of California Press, , Pursuit of Equality in American History (University of California Press, 1978)

, 'Historians and the Problem of Early American Democracy' (1962) 67 American Historical Review 626-46

Pollock, Sir Frederick and Frederic William Maitland, The History of English Law before the Time of Edward I (2nd edn 1898; reprinted Cambridge University Press 1968)

Powell, Walter, The New Institutionalism in Organizational Analysis (University of Chicago Press, 1991)

Putnam, Robert et al, Making Democracy Work: Civic Traditions in Italy (Princeton University Press, 1994)

Rabinow, Paul (ed), The Foucault Reader (Pantheon, 1984)

Reid, John P, 'The Rule of Law' in Jack P Greene and JR Pole, A Companion to the American Revolution (Blackwell, 2000) 645-9 , In a Defiant Stance (Pennsylvania State University Press, 1978)

Rousseau, Jean Jacques, The Social Contract (Marc Michel Rey, 1762)

Sandel, Michael, Liberalism and the Limits of Justice (Cambridge University Press, 1998)

Scheiber, Harry N, State Law and Industrial Policy in American Development 1790-1865 (Nelson A Rockefeller Institute of Government, State University of New York, 1987a) , Ohio Canal Era: A Case of Government and Economy, 1820-1861 (Ohio University Press, 1987b)

Schlesinger, Arthur, The Age of Jackson (Little, Brown, 1945)

Schmitt, Carl, The Concept of the Political (University of Chicago Press, expanded edn 2007)

Sellers, Charles, The Market Revolution (Oxford University Press, 1991)

Sewell, William H, Work and Revolution in France (Cambridge University Press, 1980)

Shalhope, Robert E, 'Republicanism' in Jack P Greene and JR Pole (eds), A Companion to the American Revolution (Blackwell, 2000)

, Bennington and the Green Mountain Boys: The Emergence of Liberal Democracy in Vermont, 1760-1850 (Johns Hopkins University Press, 1996)

Simon, Jonathan, Poor Discipline: Parole and the Social Control of the Underclass, 1890-1990 (University of Chicago Press, 1993)

Skinner, Quentin, Liberty Before Liberalism (Cambridge University Press, 1997)

Skocpol, Theda, States and Social Revolutions (Cambridge University Press, 1979)

Skowronek, Stephen, Building a New American State: The Expansion of National Administrative Capacities, 18771920 (Cambridge University Press, 1982)

Small, Albion W, The Cameralists (Franklin, 1909)

Smith, Adam, The Wealth of Nations (Strahan and Cadell, 1776)

Smith, Sir Thomas, De Republica Anglorum: A Discourse on the Commonwealth of England, L Alston (ed) (Cambridge University Press, 2009 [1583])

Smyth, Albert H (ed), The Writings of Benjamin Franklin, 10 vols (New York, 1905-7)

Somers, Margaret, Genealogies of Citizenship (Cambridge University Press, 2008)

Soysal, Yasemin N, Limits of Citizenship: Migrants and Postnational Membership in Europe (University of Chicago Press, 1995) 
Steinfeld, Robert J, The Invention of Free Labor (University of North Carolina Press, 1991)

Steinmetz, George, Regulating the Social (Princeton University Press, 1993)

Stone, Lawrence, Family, Sex and Marriage in England, 1500-1800 (Harper Perennial, 1979)

Story, Joseph, Discourse upon the Inauguration of the Author as Dane Professor of Law (Cornell Law School Library, 1829)

Story, WW, Life and Letters of Joseph Story (J Chapman, 1851)

Tadros, Victor, 'Between Governance and Discipline: The Law and Michel Foucault' (1998) 18(1) Oxford Journal of Legal Studies 75-103

Taylor, Charles, Modern Social Imaginaries (Duke University Press, 2004)

, The Liberal-Communitarian Debate (MIT Press, 1985)

Hegel (Cambridge University Press, 1977)

Thomas, Keith, 'The Levellers and the Franchise' in GE Aylmer (ed), The Interregnum: The Quest for Settlement, 1646-1660 (Palgrave Macmillan, 1974)

Thompson, EP, Whigs and Hunters (Pantheon, 1975)

, The Making of the English Working Class (Vintage, 1963)

Tomlins, Christopher, Law, Labor and Ideology in the Early American Republic (Cambridge University Press, 1993)

Tyler, Tom, 'Governing Amid Diversity: The Effect of Fair Decision-Making Procedures on the Legitimacy of Government' (1994) 28(4) Law and Society Review 809-31

Veyne, Paul (ed), A History of Private Life, Volume 1: From Pagan Rome to Byzantium, A Goldhammer (trans) (Belknap Press of Harvard University Press, 1987)

Vogel, Mary E, 'Dueling Discourses' (forthcoming)

, 'Situating Legislative Drafting' (2008) 10 European Journal of Law Reform 275-93

Coercion to Compromise: Plea Bargaining, the Courts and the Making of Political Authority (Oxford University Press, 2007a)

'Embedded Liberty: Imagining Citizenship for a World of Self-Rule. American Courts in the Early National Period' (2007b) 18 King's College Law Journal 23-60

'Lawyering in an Age of Popular Politics' in Jerry van Hoy (ed), Legal Professions: Work, Structure and Organizations (Elsevier, 2001)

, 'The Social Origins of Plea Bargaining: Conflict and the Law in the Process of State Formation, 1830-1860' (1999) 33 Law and Society Review 161-246

Warren, Charles, Jacobin and Junto (Harvard University Press, 1931)

Watson, HL, Andrew Jackson v Henry Clay (St Martin's Press, 1998)

Liberty and Power: The Politics of Jacksonian America (Hill and Wang, 1990)

Weber, Max, Economy and Society, Guenther Roth and Claus Wittich (eds) (University of California Press, 1978)

Wickham, Gary and Alan Hunt, Foucault and the Law (Pluto, 1994)

Wiener, MJ, 'Market Culture, Reckless Passion and the Victorian Reconstruction of Punishment' in TL Haskell and RF Teichgraeber III (eds), The Culture of the Market (Cambridge University Press, 1993)

Wilentz, Sean, Chants Democratic: New York City and the Rise of the American Working Class, 1788-1850 (Vintage, 1984)

Wilf, Steven, Law's Imagined Republic (Cambridge University Press, 2010)

Wood, Gordon, The Radicalism of the American Revolution (Alfred A Knopf, 1992) The Creation of the American Republic, 1776-1787 (University of North Carolina Press, 1969) 
Zuckerman, Michael, Peaceable Kingdoms: New England Towns in the Eighteenth Century (Norton, 1978)

Zuckert, Michael, 'Rights' in Jack P Greene and JR Pole (eds), A Companion to the American Revolution (Blackwell, 2000) 691-5 , Natural Rights and the New Republicanism (Princeton University Press, 1994) 